\title{
上顎洞癌の増殖態度に関する実験的研究
}

九州歯科大学第 2 口腔外科学教室 (指導: 池尻 茂教授)

\author{
安藤 龍 男 \\ （昭和46年 8 月 5 日受理）
}

（本論文の要旨は, 1969年 5 月第29回九州歯科学会総会, 1969年 9 月第 7 回日本癌治療学会総会, 1970年 4 月第 24回日本口腔科学会総会, 1970年5月第30回九州歯科学会総会, 1970年10月第 8 回日本癌治療学会総会, 1971年 5 月第31回九州歯科学会総会に拈いて発表した。なお, 本研究の一部は, 1970年度文部省科学研究費補助金で行 なった）

\section{EXPERIMENTAL STUDY ON THE MODE OF GROWTH OF CANCER ORIGINATED IN THE MAXILLARY SINUS}

\author{
By \\ Tatsuo ANDOH \\ Second Department of Oral Surgery (Director: Prof. Shigeru IKEJIRI) \\ Kyushu Dental College, Kitakyushu, Japan
}

\section{Object}

The author made an experiment with the object of determining the mode of growth of cancer originated in the maxillary sinus.

2. Material and method

In order to secure condition similar to the cancer originated in the maxillary sinus in hu man, the author selected the rabbits for their larger size and their adaptability to transplanta tion among experimental animals, and VX 2 carcinoma for tumor for its resemblance to the squamous cell carcinoma which presents an overwhelming majority in oral cancer.

The author injected the VX 2 carcinoma's homogenate at the point, $1 \sim 1.5 \mathrm{~cm}$ from the right anterior edge of the orbit on the line with the right nostril anterior of the rabbit.

The point of the needle was held in the air of the maxillary sinus. The VX 2 carcinoma's homogenate was reservoired on the floor consisting of healthy mucous membrane of the maxillary sinus. Infiltrated growth of tumor in the membrane was obserbed.

The rate of success of transplantation thus obtained was about 100 per cent.

The author observed the macroscopic, the roentgenographic, the autopsy, the microscopic findings, in accordance with the TNM classification by UICC of four groups, i. e. the seventh day (II cases), the fourteenth day (II cases), the twenty-first day (IO cases), and the twenty-eighth day (13 cases) after the transplantation.

The results thus obtained were described below.

\section{Results}

i The author noticed that sex distinction, body weight distinction and existence of nasal bleeding at the time of transplantation of $\mathrm{VX} 2$ carcinoma's homogenate into the maxillary sinus of the rabbits had no variance on the success of transplantation.

ii The VX 2 carcinoma's homogenate transplanted in the maxillary sinus was allowed to 
run down the wall of the maxillary sinus, and gathered at the dent, or the bottom in the maxillary sinus. The author noticed growth of the tumor cells and increasing in size of the tumor at this location.

iii After the transplantation, the tumor cells infiltrated into the mucouse membrane and the submucouse membrane tissues of the maxillary sinus of the rabbits (the seventh day).

The maxillary sinus were filled replete with the VX 2 carcinoma (the fourteenth day).

The tumor next infiltrated into the outer bone and soft tissues of the maxillary sinus of the rabbits causing the tissues to recede. The surrounding tissues were also infiltrated and destroyed (the twenty-first day).

The tumor, then, increased with a particular rapidness in the facial-buccal direction (the twenty-eighth day).

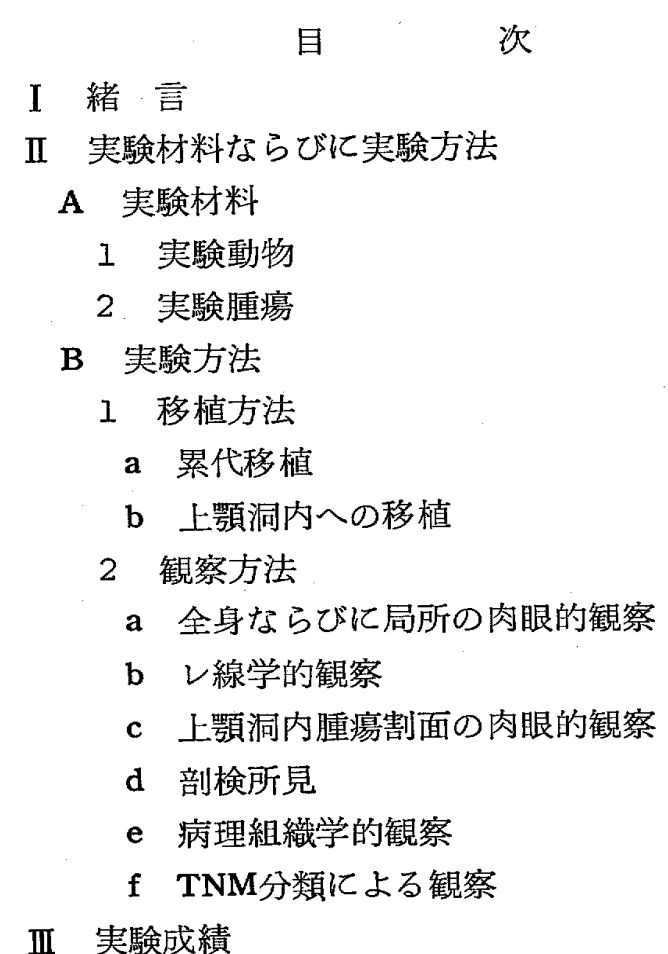
A 移植後 7 日群
B 移植後14日群
C 移植後21日群
D 移植後28日群

IV 総括ならびに考按

$\mathrm{V}$ 結 論

VI 参考文献

\section{I 緒言}

人の顎口腔領域における悪性腫瘍は，直視可能なもの が多く, 他科領域の内藏癌にくらべ, その病状や経過な どの観察は，此較的容易である。しかし，上顎洞粘膜に 初発する所謂中心性上頡癌では，口腔側に潰瘍を形成す
るか，あるいは外貌に一見して分るような腫瘤を形成す るまでは，その経過を正確に観察することは容易ではな く, 従って，その実体を完全把握するのはさらに困難で ある。

てのような癌を早期に診断し，病像を把握し，より効 果的な治潦を行なうためには，上顎癌の増殖態度を充分 解明するととが必要である。しかしながら，ての解明を 人癌で具体的に行なうことは出来ない。しかも，実験的 研究についても，その報告は少なく，ただ，芦原》，平 野16)らの報告が，わずかに本問題にふれているのみであ る.

そとで，上顎洞粘膜に原発する癌の增殖態度の様相を 実験的に解明するために，以下のような実験を行ない， 興味ある知見を得たので，報告する。

\section{A 実験材料}

II 実験材料ならびに実験方法

1 実験動物

動物は，体重 $2000 \mathrm{~g}$ 前後の雑系白色家兔である。購入 後, 温度調節装置を施した実験動物含内の Immortal $\mathbf{R}$ - 3 A型ケージ中に入れ，1日量， ORIENTAL RC5 固型飼料 $130 \mathrm{~g}$ と水 $300 \mathrm{ml}$ で, 5 日間以上飼育し, この 環境に充分慣れた健康な家兔を実験に供した。 なお，実験期間中も同じ条件下で飼育した。

2 実験腫湯

VX2 carcinoma を実験に供した。

VX2 carcinoma は VX7 carcinoma とともに shope 乳頭腫・癌系列 $57,58,59,60,62$ ) 偊する virus産性の可移植 性癌である。

本腫瘍は，1940年 Rous33,51) 引によって可移植性癌 腫に確立され，1963年 伊藤34により日本へ移入され， 
愛知がんセンター・ウイルス部で維持されている.

著者は，本腫瘍の 220 (54) 代目の腫痬を愛知がんセ ンター・ウイルス部（カッコ内の数字は，ウイルス部で 行なった累代数を示す）より譲与を受け，著者が累代移 植を行なう一方，家鬼の顎口腔領域へ移植し，ほぼ 100 \%の移植陽性率を得たものを使用した（Fig. I）。

なお，著者の累代移植は 1971 年 4 月現在，36代を数 え, 一方, 口腔領域への累代移植にも成功しているもの である。

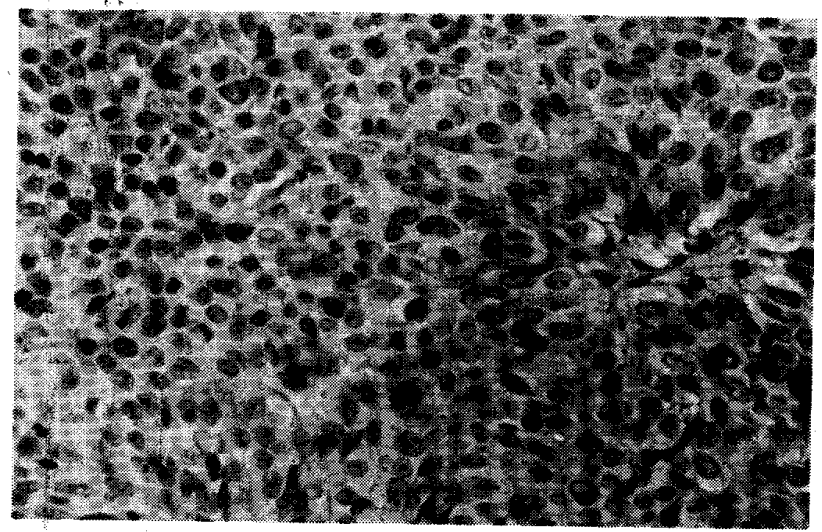

Fig. 1 Histo-pathologic picture of the $V \times 2$ carcinoma $(150 \times)$.

The VX2 carcinoma is a squamous cell carcinoma of lower kerato and differentiated degree.

The 35th generation of succesive transplantation by the author.

B 実験方法

1 移植方法

a 累代移植

木村34)，松尾40)，森下44)，MORI11）の方法を参考 に，著者独自の方法で行なった。すなわち，大腿筋肉に 鵟卵大以上の腫瘤が触知出来る移植後25日目頃，乙れを できるだけ無菌的に摘出し，このうち壊死におちいって いない発育の旺盛な腫湯細胞層のみを取り出し, 腫汮諊 を作製した。

これを Diffco 製 Medium Eagle で5倍に稀釈し細 胞を浮游させ, 300 mesh で滤過し, さらに二重ガーゼ を通して細胞数が50 × $104 / \mathrm{mm}^{3}$ になるよう調製した。 この細胞浮游液の0. $5 \mathrm{ml}$ を19G×1/2の針を介し，あらか じめ準備して拈いた健康な家自の大腿筋肉入移植し，約 25日間隔で累代移植を行なった。

\section{b 上顎洞内への移植}

洞内への移植には，累代移植に使用した腫瘍細胞浮游 液をそのまま用いた，移植時の注射針の刺入部位は，家 鬼の右側眼窝最前縁亡右外鼻孔を結ぶ仮線上で眼窝より 1. 0 1. $5 \mathrm{~cm}$ 鼻孔に近い点を刺入点とし，とれより骨面 にほぼ垂直な方向へ0.3〜0.5cm 針を進め，Fig. 2 に示 すように洞控内に針先がとどまった状態で注入出来るよ う考慮し，移植した。

なお，移植を右側だけに限定したのは，家㥁を屠殺し 観察する際に，健側との混淆を避けるためである。

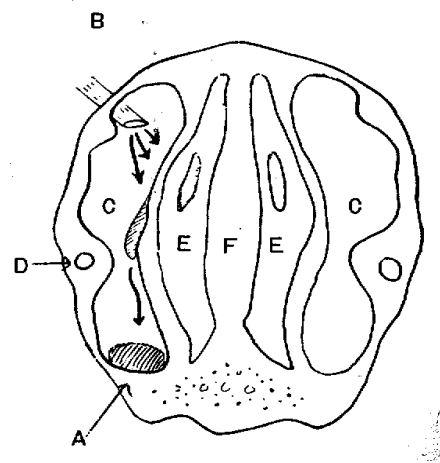

Fig. 2 The method of transplantation of the VX2 carcinoma's homogenate.

A: VX2 carcinoma's homogenate

B: needle for transplantation

C: maxillary sinus of the rabbit

$\mathrm{D}$ : canalis nasolacrimalis

E: cavum nasi

F: septum nasi

2 観察方法

移植後，7日，14日，21日，28日の 4 群の観察日をむ うりた. 観察日に腫痬家克を耳静眽より空気栓塞をおこ させ屠殺し，次のような諸点について観察した。

実験家忽数は，7日群は11羽，14日群は11羽，21日群 は10羽，28日群は13羽である。

\section{a 全身ならびに局所の肉眼的観察}

腫瘍を移植したあと, 腫癔の増殖状態および, それに ともなう家兔の全身ならびに局所の諸変化を肉眼的に観 察した。

\section{b V線学的観察}

観察日に屠殺した家后を伏卧位の状態で，上顎洞を中 心としてレ線撮影し, 腫湯の増殖状態をレ線学的に観察 した.

\section{c 上䕱洞内腫瘍の肉眼的観察}

上顎洞内で発育した腫湯を観察するため，屠殺した家 鬼の頭蓋骨を通法に従って10\% Formalin 水溶液で固定 し，水洗したあ亡電気脱灰した。

肉眼的観察を立体的にするため, 家秉頭盍骨に，Fig. 3 に示す点をそれぞれ含む前頭断面，矢状断面，水平断 面の 3つの面を設け，常に同一の解剖学的位置，方向よ り腫瘍の増殖態度が観察出来るよう考慮をはらった。

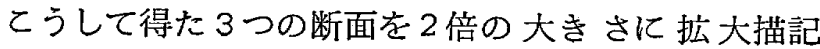


し, 腫瘍の増殖態度を観察した。 また, 腫瘍増殖状態の 観察を容易にするために，必要に応じて他の任意切断面 を作り観察した。

Fig. 3 Three sectional planes for observation of the intramaxillary sinus.

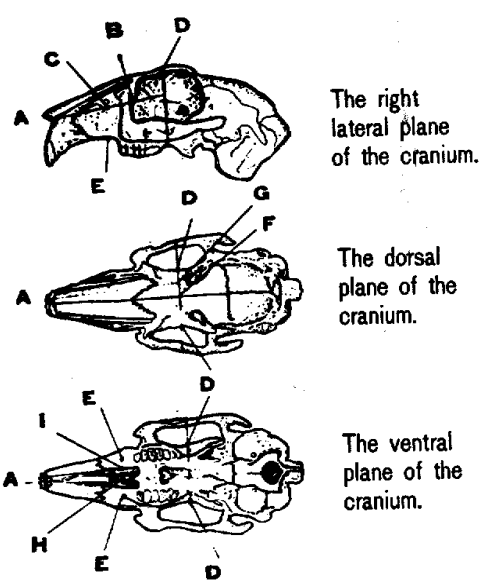

A: nostril

B: anterior edge of the orbit

C: point of injection

for transplantation

D: upper edge of the orbit

E: point, $0.5 \mathrm{~cm}$ forward of the molar tooth

F: crossing point of the median line and the line with the point $D$.

G: point, $0.5 \mathrm{~cm}$ forward of the point $F$.

$H$ : crossing point of the median line and the line with the point $E$.

1: point, $0.4 \mathrm{~cm}$ forward of the point $\mathrm{H}$.

The frontal sectional plane encompassing point $C$

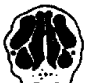
and $E$ of the right and the left.

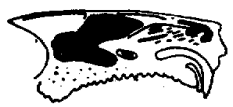

The sagittal sectional plane encompassing point $A, G$ and $I$.

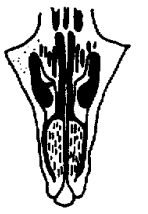

The horizontal sectional plane encompassing point $A$ and $B$ of the right and the left.

d 剖検所見

屠殺した家兔は，全例剖検し，䪽下部，頸部，胸部， 腹部の各臟器における転移状態を検 索した。肺の転移 は，その度合で下記のでとく分類した。

肺の転移巣は，実験期間中で栗粒大から米粒大にとど まり，それ以上の腫瘍塊を形成したものはなかった。

\section{$+\cdots \cdots \cdot \cdots$ 転移結節が10個以下 \\ H…….転移結節が11 50個 \\ H.........転移結節か $551 １ 00$ 個 \\ ⿻․………転移結節が100個以上 \\ e 病理組織学的観察}

上顎洞内一移植した本腫瘍は，肉眼的には経日的に增 殖し，転移病巣を形成したが，乙れが果して VX 2 Carcinoma であるかどうかを確認することを主目的に病理 組織標本を作製し検索した。

また，本腫瘍が周团の軟組織，硬組織などにおよほすす 影響を知るために，標本を全割あるいは数個所の小分割 によって作製し，鏡検した。
標本は, Celloidin あるいは Paraffin 包埋とし Hematoxylin・Eosin 重染色を施し，検索した。

f TNM分類による観察

剖検時の観察結果を, UICC 35,48) より提示されている TNM 分類および北村 ${ }^{35)}$ ，酒井48) らの報告にもとづき上 顎洞の悪性腫場を分類した。

\section{III 実 験 成 績}

家鬼の実験番号 (以下No. とする)，実験 日数，性 別, 実験季節, 移植時体重, 屠殺直前の体重, 腫㷚の大 きさ（縦 $\times$ 横 $\times$ 高さ）などの所見については，Table I に示す通りである。

\section{A 移植後 7 日群}

この実験群はNo. エ〜11の11羽である.

1 性別; 古は7 例 (No. 2，3，5，8，9，10， 11) で, 早は 4 例 (No. 1, 4, 6, 7) であった.

2 実験季節；春に行なったもの 2 例 (No. 10, 11), 夏に行なったもの工例（No. I），秋に行なったあの5 例 (No. 2，3，4，5，6），冬に行なったあの3 例 (No. 7, 8, 9) であった.

3 移植時体重; No. 8 は，2730g でやや大きめであ ったが，その他のもの (No. 1，2，3，4，5，6， $7,9,10$, 11) は2000g前後であった.

4 移植時の家兔の所見; No. 9 は移植 後, 右側鼻出 血がみられたが，自然止血をまってゲージに入れた，そ の他のもの (No. 1, 2, 3, 4, 5, 6, 7, 8, 10,11）には，特に異状はなかった。

5 屠殺直前の全身抢よび局所所見; 病死したと考え られる No. 7 を除く他の腫汮家兔（No. 1，2，3， $4,5,6,8,9,10,11)$ は, 与えた飼料, 水を残 すととなく健康家兔之ほほ同様な生活状態であった。乙 のうち 9 例 (No. 1, 2, 3, 4, 5, 6, 7, 10, 11 ）に10 110gの体重増加が観察され，2 例（No. 8，9 ）に10〜30gの体重隇少がみられた。

局所的には，全例（No. 1〜11）特に変った所見は観 察されなかった。

6 ᄂ線学的観察; 全例 (No. I II) K, 特記すへ き変化はみられなかった（Fig. 4).

7 腫瘍割面の肉眼的観察; 4 例 (No. 3，4，9, 10）に変化がみられた。すなわち，粟粒ないし米粒大の チョコレート様あるいは血餅用のものが, 上類洞底の前 方部（No. 3，4，10） あるいは洞内 の側壁宿凹部（ No. 9) に確認された（Fig. 5). 他の 7 例（No. 1, $2,5,6,7,8,11)$ には変化は発見出来なかっ 
Table 1 The table showing the result

\begin{tabular}{|c|c|c|c|c|c|c|}
\hline case number & $\begin{array}{l}\text { the number of } \\
\text { day after the } \\
\text { transplantation }\end{array}$ & sex. & month & $\begin{array}{l}\text { body } \text { weight at the } \\
\text { tumor } \\
\text { transplantation ( } g \text { ) }\end{array}$ & $\begin{array}{l}\text { body weight when } \\
\text { slaughtered }\end{array}$ & $\begin{array}{l}\text { size of tumor } \\
\text { growth (length } X \\
\text { width } X \text { height) } \\
\text { (cm) }\end{array}$ \\
\hline 1 & 7 & 우 & 6 & 2050 & 2160 & not noticeable \\
\hline 2 & 7 & $\hat{o}$ & 11 & 2100 & 2200 & not noticeable \\
\hline 3 & 7 & $\hat{o}$ & 11 & 1980 & 2010 & $0.5 \times 0.4 \times 0.3$ \\
\hline 4 & 7 & 우. & 11 & 2100 & 2170 & $0.3 \times 0.4 \times 0.5$ \\
\hline 5 & 7 & $\hat{\sigma}$ & 11 & 2200 & 2250 & not noticeable \\
\hline 6 & 7 & 우 & 11 & 2300 & 2350 & not noticeable \\
\hline 7 & 7 & 우 & 1 & 2050 & 2100 & not noticeable \\
\hline 8 & 7 & $\hat{\delta}$ & 1 & 2730 & 2700 & not noticeable \\
\hline 9 & 7 & $\hat{\delta}$ & 1 & 2350 & 2340 & $0.6 \times 0.2 \times 0.2$ \\
\hline 10 & 7 & 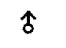 & 3 & 2060 & 2100 & $0.2 \times 0.1 \times 0.2$ \\
\hline 11 & 7 & $\hat{\delta}$ & 4 & 2240 & 2250 & not noticeable \\
\hline 12 & 14 & $\hat{\delta}$ & 6 & 2000 & 2450 & $1 \times 0.8 \times 1.3$ \\
\hline 13 & 14 & q & 6 & 1880 & 2350 & $1.7 \times 0.8 \times 1.4$ \\
\hline 14 & 14 & $\hat{\delta}$ & 9 & 2320 & 2410 & $1.4 \times 0.3 \times 0.6$ \\
\hline 15 & 14 & $\hat{\delta}$ & 10 & 2450 & 2560 & $0.2 \times 0.3 \times 0.2$ \\
\hline 16 & 14 & 우 & 11 & 2500 & 2470 & $2 \times 1.5 \times 3$ \\
\hline 17 & 14 & $\uparrow$ & 12 & 1900 & 2100 & $0.3 \times 0.2 \times 0.4$ \\
\hline 18 & 14 & $\delta$ & 12 & 2800 & 2910 & $0.2 \times 0.1 \times 0.2$ \\
\hline 19 & 14 & 우 & 2 & 2500 & 2450 & not noticeable \\
\hline 20 & 14 & 우 & 6 & 2300 & 2450 & $1.8 \times 1.1 \times 1$ \\
\hline 21 & 14 & 우 & 6 & 2550 & 3000 & $0.7 \times 0.3 \times 0.1$ \\
\hline 22 & 14 & $\hat{\delta}$ & 6 & 2450 & 2910 & $0.3 \times 0.4 \times 0.2$ \\
\hline 23 & 21 & $\hat{\jmath}$ & 4 & 1910 & 1780 & $1.5 \times 1.5 \times 1.5$ \\
\hline 24 & 21 & 우 & 5 & 1760 & 1630 & $1.5 \times 1.5 \times 1.5$ \\
\hline 25 & 21 & 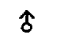 & 8 & 2200 & 2000 & $2.5 \times 1.8 \times 2$ \\
\hline 26 & 21 & $\hat{\jmath}$ & 9 & 2400 & 2050 & $4.1 \times 3.5 \times 2.3$ \\
\hline 27 & 21 & $\hat{\delta}$ & 9 & 2200 & 1850 & $3 \times 1.5 \times 2$ \\
\hline 28 & 21 & q & 9 & 2300 & 1800 & $2.5 \times 2 \times 1.4$ \\
\hline 29 & 21 & $\hat{\delta}$ & 5 & 2370 & 2200 & $3 \times 1.4 \times 1.5$ \\
\hline 30 & $2 !$ & $\hat{o}$ & 12 & 2100 & 2150 & $1.5 \times 1.5 \times 1.5$ \\
\hline 31 & 21 & 우 & 5 & 2200 & 2300 & $.2 .8 \times 1.7 \times 1.2$ \\
\hline 32 & 21 & 우 & 5 & 2100 & 1900 & $2 \times 4 \times 1.2$ \\
\hline 33 & 28 & $\hat{\delta}$ & 4 & 2170 & 1700 & $6.5 \times 4.5 \times 4$ \\
\hline 34 & 28 & $\hat{\delta}$ & 5 & 2400 & 1880 & $4 \times 1.1 \times 1.5$ \\
\hline 35 & 28 & 우 & 5 & 1550 & 1020 & $2.2 \times 2.7 \times 1.7$ \\
\hline 36 & 28 & $\hat{\delta}$ & 6 & 2270 & 1760 & $6.5 \times 4.5 \times 4$ \\
\hline 37 & 28 & $\delta$ & 7 & 2300 & 2100 & $2 \times 1.5 \times 2$ \\
\hline 38 & 28 & 우 & 10 & 1850 & 1320 & $6.5 \times 4.5 \times 4$ \\
\hline 39 & 28 & 우 & 12 & 2500 & 2610 & $1.4 \times 0.8 \times 1$ \\
\hline 40 & 28 & $\hat{\delta}$ & 1 & 2200 & 2050 & $1 \times 1 \times 1.5$ \\
\hline 41 & 28 & 우 & 3 & 2150 & 2360 & $0.6 \times 0.3 \times 0.5$ \\
\hline 42 & 28 & 우 & 3 & 2300 & 1700 & $4 \times 1.5 \times 1.5$ \\
\hline 43 & 28 & 우 & 6 & 2300 & 1790 & $6.5 \times 4 \times 4$ \\
\hline 44 & 28 & $\uparrow$ & 6 & 3000 & .2550 & $6 \times 5 \times 5$ \\
\hline 45 & 28 & $\hat{o}$ & 6 & 2300 & 1550 & $6.5 \times 5 \times 5$ \\
\hline
\end{tabular}




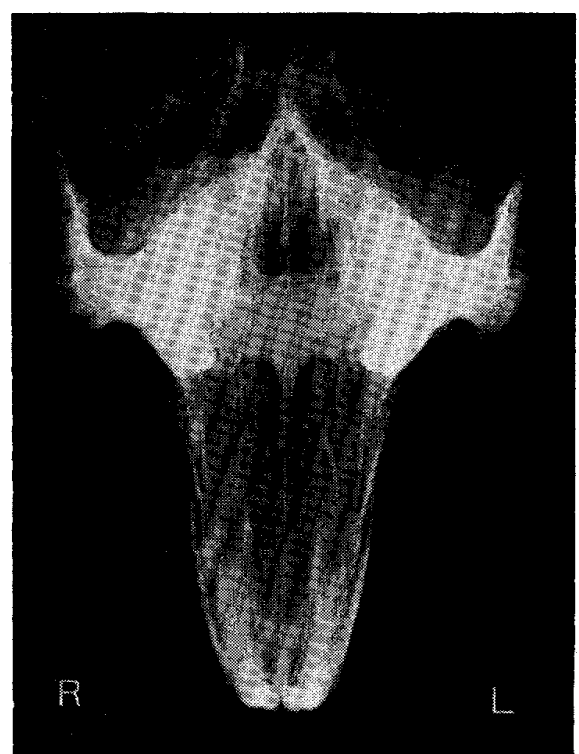

Fig. 4 -Ray photo on the seventh day (case No. 9). Not remarkable in this photo.

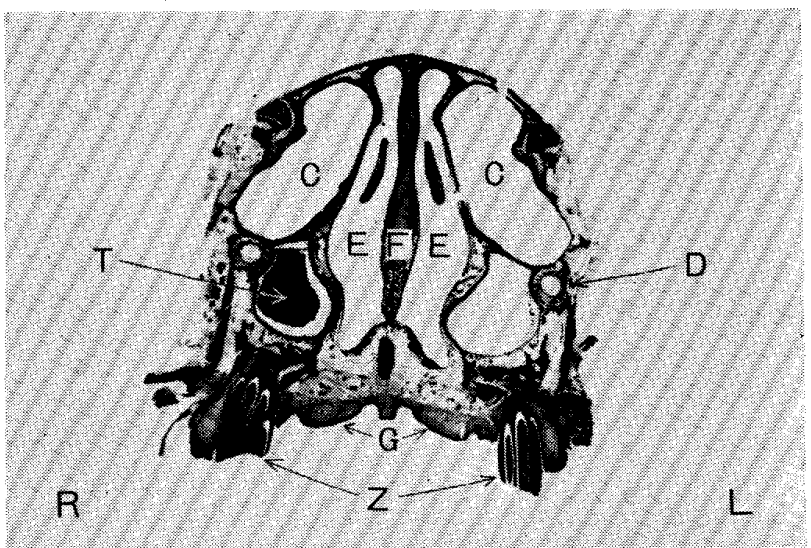

Fig. 5 Histo-pathologic picture of the frontal sectional plane on the seventh day (case No. 3)

$\mathrm{T}$ : tumor

$\mathrm{D}$ : canalis nasolacrimalis

E: cavum nasi

F: septum nasi

C: maxillany sinus

G: palate

Z: teeth

た。

8 剖検所見；2 例 (No. 3，4）に変化があった. すなわち，No. 3 は右側顎下リンパ節が軽度に腫脹し， No. 4 は右側顎下リンパ節および頸部リンパ節が軽度に 腫脹していた。その他の 9 例 (No. 1，2，5，6， $7,8,9,10,11)$ には変化は認められなかった.

9 病理組織学的観察; 肉眼的にII例 (No. 1 II) 中 4例 (No. 3，4，9，10) にチョコレート様あるい は血餅様のものが洞底壁に附着した状態で観察された。
(Fig. 6). との部分の洞壁を含め病理組織標本を作製 し検索した. チョコレート様あるいは血餅様の大部分 は，壊死組織様のものや炎症性細胞などから成り，新生 血管，腫瘍細胞の増殖は認められなかった。しかし，洞 粘膜に接する部分では，活力のある腫瘍細胞が，炎症性 細胞に富んだ粘膜上皮下に洞粘膜上皮を排除または破填 しながら，浸潤する像が認められた（Fig. 7，8). これらの1例（No. 3）において腫瘍細胞は，洞内軟組 織（洞粘膜および粘膜下組織）中に小胞巣を形成しなが ら，浸潤増殖していた。骨組織の破壊は全く認められず 軟組織のみを浸潤していた，その他のあの（No. 1， $2,5,6,7,8,11)$ には病変は認められなかっ た. 腫脹していたNo. $3 ， 4$ ，の顎下リンパ節には転移 は認められなかった。

10 TNM 分類による観察；該当するあのはなかった.

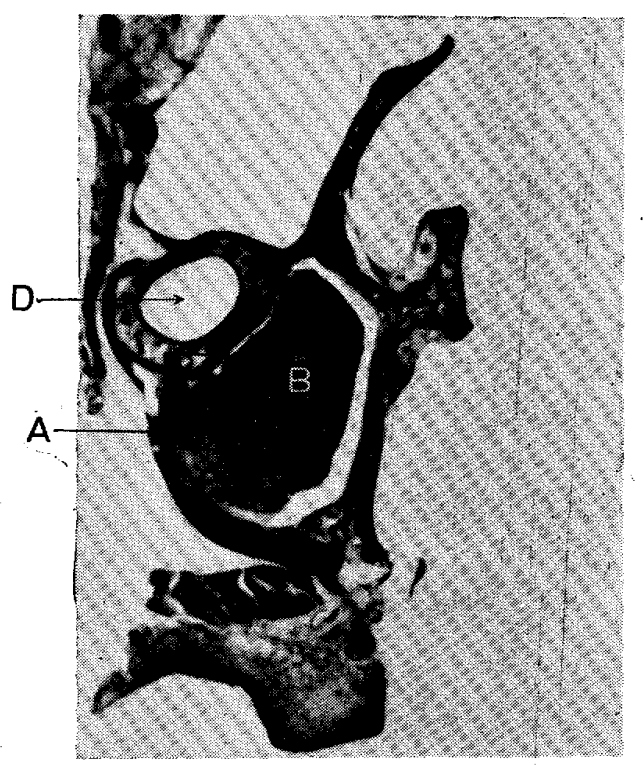

Fig. 6 Histo-pathologic picture on the seventh day (Case №.9). A: tumor cells infiltrated at this location.

B: consists of inflammatory cells and similar tissues of necrosis. (In macroscgpic observations, these presented the appearance of blood clot or chocolate like color.)

$D$ : canalis nasolacrimalis

B 移植後14日群

この実験群はNo. 12〜22011羽である.

1 性別; 合は 6 例 (No. 12, 14, 15, 17, 18, 22) で早は 5 例 (No.13, 16, 19, 20,21) であった.

2 実験季節；夏に行なったもの 5 例 (No. 12，13， $20 ， 21 ， 22$ ), 秋に行なったもの 3 例 (No. 14, 15, 16), 冬に行なったもの3 例 (No. 17, 18, 19) であっ た.

3 移植時体重；No. 18は体重2800gで, やや大きめ 


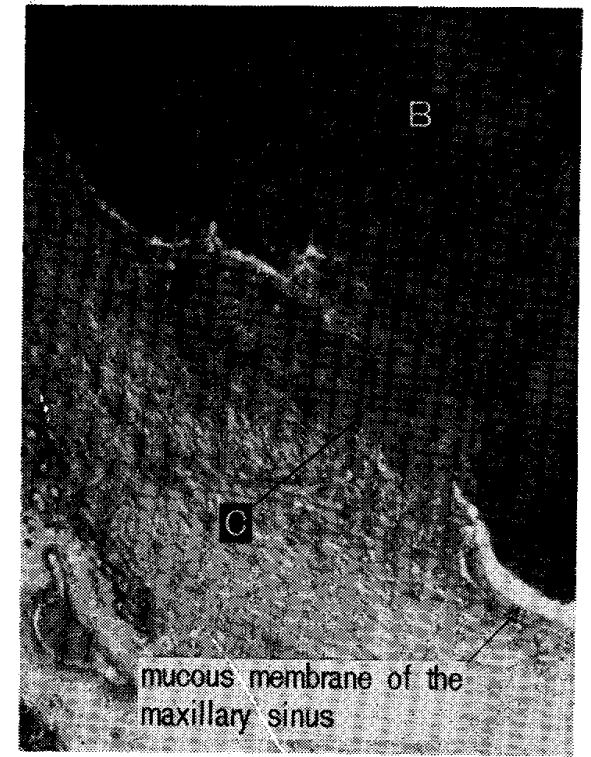

Fig. 7 Shows the growth of the tumor.

Enlanged histo-pathologic picture of part A of fig.6.

B: consists of inflammatory cells and tissues similar to necrosis.

C: tumor cells infiltrated at this location $(40 X)$.

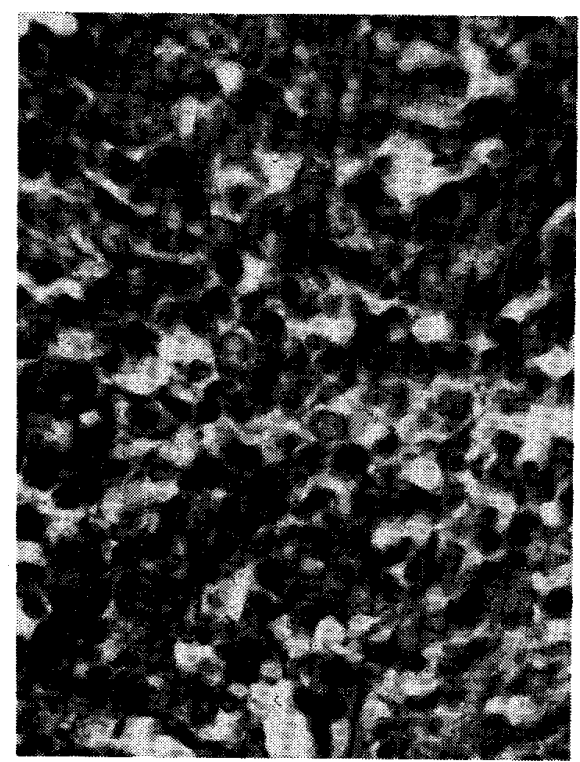

'Fig. 8 The VX2 carcinoma

Enlarged histo-pathologic picture of part $\mathrm{C}$ of fig. 7 .

The VX2 carcinoma's cells lie scattered in the majority of inflammatory $(200 X)$.

であったが, その他のもの（No.12, 13, 14, 15, 16, $17,19,20,21,22)$ は2000g前後であった.

4 移植時の家克所見； 4 例 (No. 13, 15, 21，22） は，移植後に右側鼻出血があったが，特別な処置を要せ ず止血した，その他のもの（No. 12, 14, 16, 17, 18, 19，20）には，特に異常はなかった。

5 屠殺直前の全身および局所所見；腫瘏家自は，健 康家兔之ほぼ同様で，与えた飼料および水は残すとこな
く元気であったが, 9 例 (No. 12, 13, 14, 15, 17, 18,20，21，22）に50 470g の体重増加が観察され, 2 例（No. 16，18）に30〜50gの体重減少がみられた。

局所については，右側に軽度の舅汁，流涙が認められ たもの1例 (No. 16), 右側上顎煩部に下在組織と可動性 のない腫溜 (Fig. 9) が認められたもの2 例 (No.16, 20) が観察されたが， その他の 9 例 (No. 12，13，14, $15,17,18,19,21,22)$ は健康家克亡ほぼ同様であっ た。

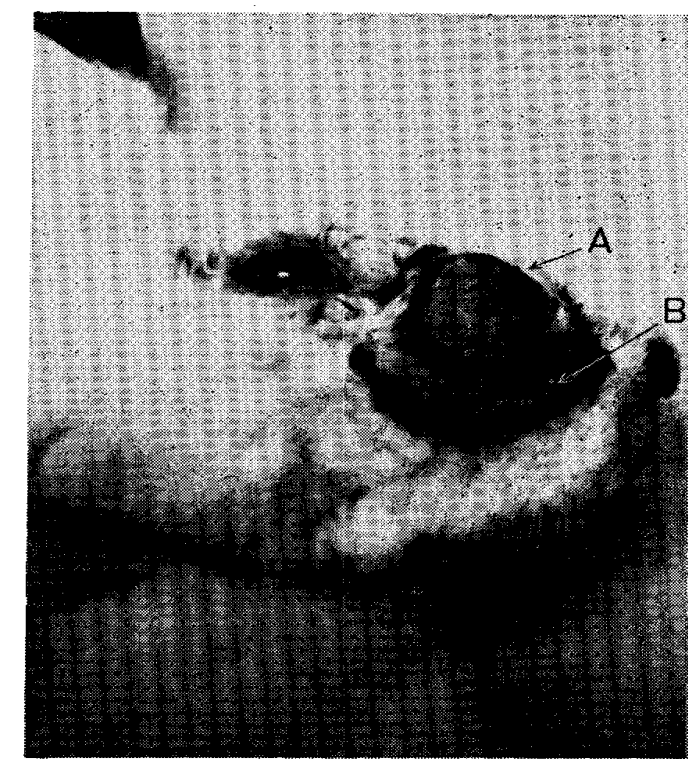

Fig. 9 Black line shows macroscopic sphere of the tumor growth, which was transplanted in maxillary sinus.

A: macroscopic sphere of tumor growth on the fourteenth day

8: macroscopic sphere of tumor growth on the twenty-first day.

6 レ線学的観察 ; 右側上顎洞相当部に軽度の透過性 減少を認めたものは 5 例 (No. 12, 13, 14, 16, 20) でささらに煩側部の骨柱が異常陰影を示したり，一部消 失したもの 3 例 (No.12, 13, 14) (Fig. 10) で, 特に No. 20 右側上顎洞部の淡明像に対応する骨質外に0.7 $\times 1.5 \mathrm{~cm}$ 大の不透過像を認め, No. 16 は右側上顎頓側部 に1×1×0.5cm大の小丘状の像が観察された.

その他の 6 例 (No.15, 17, 18, 19, 21, 22) には変 化はみられなかった。

7 腫瘍割面の肉眼的観察；10例 (No. 12, 13, 14, $16,17,18,20,21,22)$ 亿変化があった. とのうち 4 例 (No. 15, 17, 18, 22) は, 右 側 上鿓洞 底 部の前方 (No. 15，18，22）あるいは中央 (No.17) に粟粒ない し米粒大のチョコレート様あるいは血餅様附着物が認め られた. 


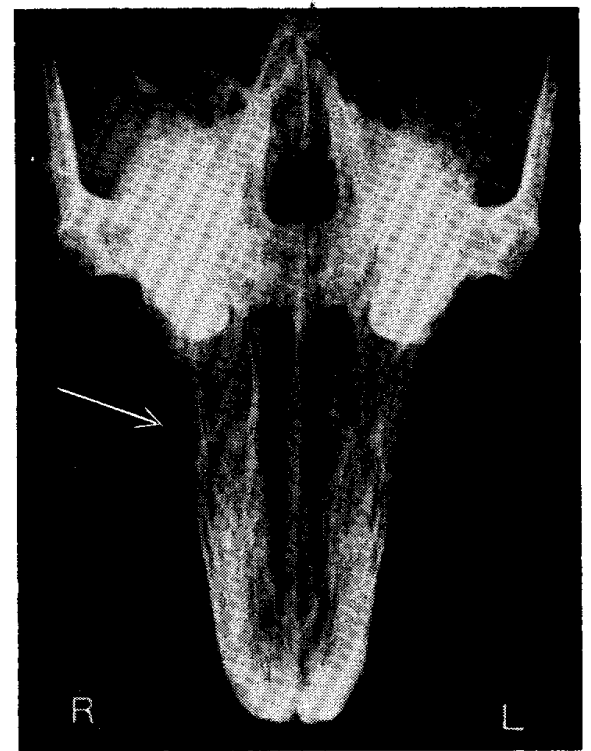

Fig.10 X-Ray photo on the fourteenth day (case No. 12). Radiolucent areas descreased at the right maxillay sinus. The bone subsance of the outer side of the maxillary sinus disappeared in part

他の 6 例（No.12，13，14，16，20，21） には VX2 carcinoma 增殖の所見があった。すなわち No.14，21は 洞内に腫瘍が限局した所見が認められ，No. 12，13では 洞内ばかりではなく, 鼻腔 (No. 12) や穊骨洞（No. 12，13）などへあ達する所見があった．No. 20 では鼻 腔，笁骨洞の一部ばかりではなく，上顎煩側部骨壁を破 壊し軟組織へ達する所見が観察され，No.16 では上顎稹 側部の軟組織に小指頭大の腫溜形成が認められた。

No. 19には変化はみられなかった。

8 剖検知見 ; 7 例 (No. 12, 13, 15, 16, 20, 21, 22）に右側枵下リンパ節の腫脹が観察され，さらにNo. $20 ， 21 ， 22$ 亿は頸部リンパ節に，No.16 亿は左側顎下抏 よび頸部リンパ節にも腫脹が認められた。 これらの腫脹 程度は米粒大から帽針頭大であった。

9 病理組織学的観察; VX2 carcinoma の組織所見 が認められたあのは11例中10例 (No. 12, 13, 14, 15, 16, 17, 18, 20, 21，22) であった (Fig. 11). No. 19 には病変は認められなかった。

腫脹していたNo.16，20の右側㖽下リンパ節には， V X2 carcinoma の組織所見が観察されたが， その他の 家鬼のリンパ節（No.12１3，15，21，22）には，浮腫 の所見のみであった。

10 TNM 分類に上る観察；腫瘍を認めた 6 例 (No. 12, 13, 14, 16, 20, 21) は, [Stage II ${ }^{38)}$ で $\mathrm{T}_{2} \mathrm{NoMo}$

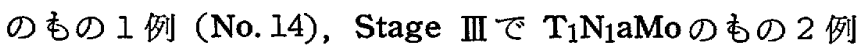
(No. 12, 21), $\mathrm{T}_{2} \mathrm{~N}_{1} \mathrm{aMo} の あ の 1$ 例 (No. 13), $\mathrm{T}_{3} \mathrm{~N}_{1}$

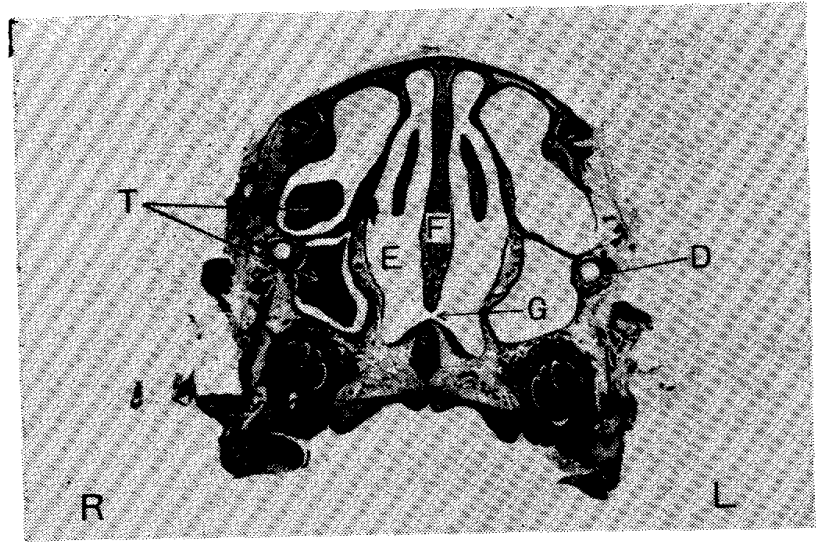

Fig.11 Histo-pathologic picture of the frontal sectional plane on the fourteenth day (case No. 12)

The tumor occupied most of the right maxillary sinus. T: tumor

D: canalis nasolacrimalis

E: cavum nasi

F: septum nasi

G: window of septum nasi

$\mathrm{bM}_{1}$ のものI例 (No. 20), $\mathrm{T}_{3} \mathrm{~N}_{2} \mathrm{bMo}$ のあのI例 (No. 16 )であった.

C 移植後21日群

ての実験群は, No. 23〜32の10羽である.

1 性別; 占洁 6 例 (No. 23, 25, 26, 27, 29, 30) で早は 4 例 (No. 24, 28,31,32) であった.

2 実験季節；春に行なったもの5 例（No. 23，24, 29，31，32), 夏に行なったもの工例（No. 25）, 秋に行 なったあの3 例（No. 26，27，28），冬に行なったもの I例 (No.. 30) であった.

3 移植時体重; 全例 (No. 23 32), 体重2000g前後 であった.

4 移植時家鬼の所見； 3 例 (No. $28,29,31$ ) は, 移植後, 右側鼻出 血があったが数 分で自然止血した。 No. 32 は，刺入時に右側眼角静脈を傷つけたので，この 部位からの出血があったが，圧迫を行ない容易に止血し た.

その他のもの（No. 23, 24, 25, 26, 27, 30）には, 特に異常はなかった.

5 屠殺直前の全身および局所所見; 腫瘍家鬼は全例 (No. 23 32), 飼料を10〜70g, 水 30〜150ml をのとし ていた。 しかし，5 例 (No. 23, 24, 29, 30, 31) に 100 130gの体重增加加観察され， 5 例（No. 25，26， 27，28，32）に200～500gの体重減少が認められた。局 所的には, 全例 (No. 23 32) に右側上領頓側部に $2 \times$ $2 \times 0.5 \mathrm{~cm}$ 大の骨様隆起ないし小指頭大の腫瘤形成が認 められた。 てれら腫瘍の増殖によっておてる鼻閉, 鼻汁 
などの鼻症状が 4 例（No. 25，27，29，31）に観察され た. この 4 例のうち2 例（No. 27，31）には，鼻症状に 続発して飼料摂取障害が起った.

6 V線学的観察; 全例 (No. 23〜32) K, ほ其通 した所見が観察された。すなわち，右側上顎洞部あるい は鼻腔は，一様に不透過像を呈し，乙の部の外方にあた る上顎骨頓側部の骨柱は乱れ，骨皮質の断像裂がみられ た. 上顎洞に対応する骨質外側には骨皮質より $I \times 0.3$ $\mathbf{c m}$ 大あるいは小指頭大ないし小鵎卵大の半球状, 雲絮 状の不透過像がみられた（Fig. 12).

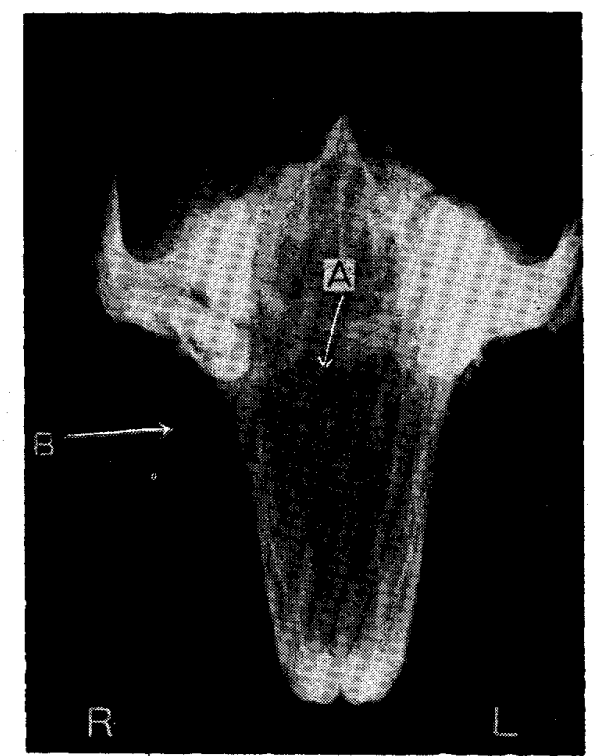

Fig.12 X-Ray photo on the twenty-first day (case No. 24 ). A: bone absorption in the surrounding tissues of maxillany sinus is observed.

B: clouded radioopaque areas rising $2 \times 0.5 \mathrm{~cm}$ in size were observed at the outer side of the maxillary sinus.

7 腫瘍割面の肉眼的観察 ; 全例 (No. 23 32) 飞腫 痬が洞内を占拠している所見があった．とのうち6例 (No. 25，26，27，28，29，31）は，周囲組織に浸潤増 殖して, 固有上顎洞の原型が失なわれていた. 上方は上 顎洞乙節骨洞が交通する部分（No. 23，24，30）あるい は穊骨洞の一部（No. 25，26，28，29，32）または穊 骨洞全域 (No. 27，31）に達し，No. 27 ではこの部分か らさらに反対側の笁骨洞, 鼻腔へ達していた。 下方は洞 底の骨内（No. 23〜32）に浸潤していた。穊骨洞の骨壁 を破壞し鼻骨に達したり，口盖側に腫瘍や潰痬を形成し たものはなかった，前方は，前鼻甲介の一部（No. 23， $24 ， 25 ， 26 ， 28 ， 30 ， 32$ ) あるいは全域 (No. 27) 八達 し, 後方は上䫟洞後壁内（No. 23，24，25, 26, 27, 28，29，30，31，32）に浸潤していた. なかです No. 31 は、顎洞後壁内の腫瘍が眼窩骨壁を眼球方向へ圧排する
態度を示し, 眼窩の前面は，わずかに後方へ突出してい たが，眼窩底への浸潤増殖は，全く認めなかった。内方 は洞の鼻側壁骨内におよぶもの（No. 23，24，30），鼻 腔の一部に達するもの（No. 26，28，31，32)，あるい は鼻腔の全域を腫瘍が占拠し，鼻中隔に接しているもの (No. 25)，あるいは鼻中隔空 から反対側の鼻腔へ達す るあの（No. 27，29）があった，腫瘍が鼻中隔を破壊す る所見はなかったが，No. 25，27は増殖した腫瘍が鼻中 隔を圧迫し，舅中隔が左側へ彎曲した所見が認められ た。次に，外方は上顎頓側骨壁内へ浸潤し，この部を外 万人压排する態度を示すすの（No. 32），また，腫瘍が 上顎洞顆側骨壁を外方へ圧排する形態で破壊して頓部軟 組織へ達し，小指頭大ないし小鷄卵大の腫瘤を形成する もの (No. 23〜31) などが観察された.

8 剖検所見; 全例 (No. 23 32) に変化が認められ た.すなわち，右側顎下リンパ節 1 個 (No. 28, 32) な いし 2 個 (No. 23，24，25，26，30）の腫脹, および両 側䫟下リンパ節が各1個（No. 27，29，31）の腫脹した 所見が認められた，とのなかで，頸部リンパ節が】個（ No. 25, 26, 27，28，29，31) 腫脹したものが認められ た. その他，肺へ(H) (No.23, 24, 27, 28, 29, 30，31） あるいは（\#）(No. 32）の転移を形成してい た.

顎下および頸部リンパ節の腫脹の程度は，米粒大から 大豆大であり，肺の転移巣の大きさは0.05〜0.3cm大の 白色のあのであった。

9 病理組織学的観察; 全例 (No. 23 32) 飞 VX2 carcinoma の組織所見が観察された（Fig.13）。転移と 考えられた右側顎下および頸部リンパ節，さらに肺にも VX2 carcinoma の所見が認められたが, No. 27，29， 31の左側顎下リンパ節には，との所見はなかった。

10 TNM分類による観察; Stage I， Stage II に該 当するものはなかった. Stage III で $\mathrm{T}_{3} \mathrm{~N}_{1}$ bMoのもの 2 例 (No. 25, 26), StageIV で $\mathrm{T}_{3} \mathrm{~N}_{1} \mathrm{bM}_{1}$ のあの 4 例 (No. $23,24,28,30$ ), $\mathrm{T}_{3} \mathrm{~N}_{2} b \mathrm{bM}_{1}$ の の 2 例 (No. 31, 32), $\mathrm{T}_{4} \mathrm{~N}_{2} \mathrm{bM}_{1}$ のあの1例 (No. 27)， $\mathrm{T}_{4} \mathrm{~N}_{3} \mathrm{bM}{ }_{1}$ のあの1例( No. 29) などが観察された。

D 移植後28日群 この実験群は, No. 33〜45の13羽である.

1 性別; 令仕 7 例 (No. 33, 34, 36, 37, 40, 44, 45) で早淁 6 例 (No. 35, 38, 39, 41, 42, 43) であっ た.

2 実験季節 ; 春に行なったもの 5 例 (No. 33，34, 35，41，42), 夏に行なったもの5例 (No. 36, 37, 


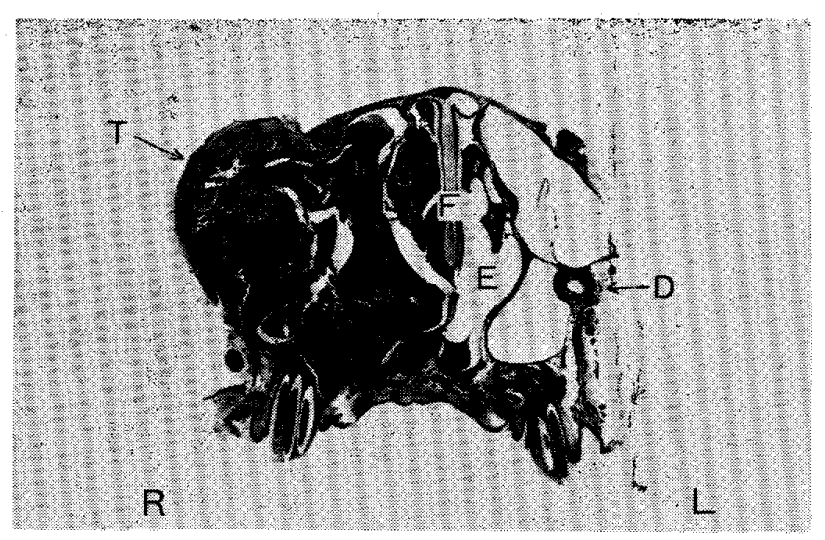

Fig.13 Histo-pathologic picture of the frontal sectional plane on the twenty-first day (case No.24).

The tumor occupied the maxillary sinus and cavum nasi

Shows the tumor growth, the size of the tip of the small finger, at the outer bone and soft tissues of

the maxillary sinus.

T: tumor

D: canalis nasolacrimalis

E: cavum nasi

F: septum nasi: bent to hearthy side

43，44，45)，秋に行なったもの工例（No. 38）, 冬に行 なったもの 2 例（No.39，40）であった。

3 移植時体重；No.35は 1550g とやや小さかったた が, その他のむの (No.33, 34, 36, 37, 38, 39, 40, 41，42，43，44，45）は2000g前後であった.

4 移植時家兔の所見；2 例 (No, 41, 44) は, 移植後 に右側鼻出血があった，とのうち，No.41は，針先か 上顎洞鼻腔側壁へ達したので針を引き戻してから移植し たが，No.44 と同様に鼻出血があった，その他のむの( No. 33, 34, 35, 36, 37, 38, 39, 40,42,43,45) に は，特に異常はなかった。

5 屠殺直前の全身および局所所見 ; 腫湯家兔のl工例 (No. 33, 34, 35, 36, 37, 38, 40, 42, 43, 44, 45) は200〜750gの体重減少がみられ，与えた飼料を40１30 g, 水を30〜300mlのとしていた。 また， 2 例（No. 39， 41）には，30〜 l logの体重増加がみられ，飼料，水とも に残すことなく健康家兔之，ほぼ同様であった。

全身的には 9 例 (No. 33, 34, 35, 36, 38, 42, 43, 44，45）に全身哀弱を認めた。 また，局所的には，ての 9 例に右側の流涙, 鼻閉, 鼻汁が認められ, 呼吸困難が 観察された。 また，煩部には小鴊卵大ないし鶏卵大の下 在組織に非可動性の腫瘤が認められた。また，No.37， 40 には右側上顎煩側部に $2 \times 2 \times 0.5 \mathrm{~cm}$ 大の. 骨様隆起な いし小指頭大の腫瘤形成加認められた。 No.39，41亿健 康家鬼亡ほぼ同様であった。

6 V線学的観察; 8 例 (No. 33, 34, 35, 38, 42, 43，44，45）に，ほぼ共通の所見があった。すなわち，
上䫇洞および鼻腔は淡明な不透過像を示し，これに対応 する煩側部の骨柱, 皮質は淡明となり異常陰影（No.

33，34，42，43，44） あるいは, また, 煩側骨壁の消失が みられた (No. 35，38，45). さらに，乙の外煩部には 小鷄卵大ないし鶂卵大の山岳状に隆起した雲絮状のレ線 陰影が観察された. No. 45には，これらの所見とともに 著明な骨吸収像, 歯牙の転位像などが認められた（Fig. 14).

3例（No. 36，37，40）は，右側 上顈，鼻腔に不透 過像がみられ，乙の部の外方にあたる上顎骨煩側部の骨 柱は乱れ，骨皮質の断裂像なざがみられた。 上類洞に対 応する骨質外側には，骨皮質より，小指頭大の半球状， 雲絮状の不透過像がみられた.

No. 39 は, 右側上澦洞相当部に軽度の透過性減少がみ られ，さらに頓側部の骨柱が一部消失した所見があっ た.

No.41には，特記すべき変化はなかった。

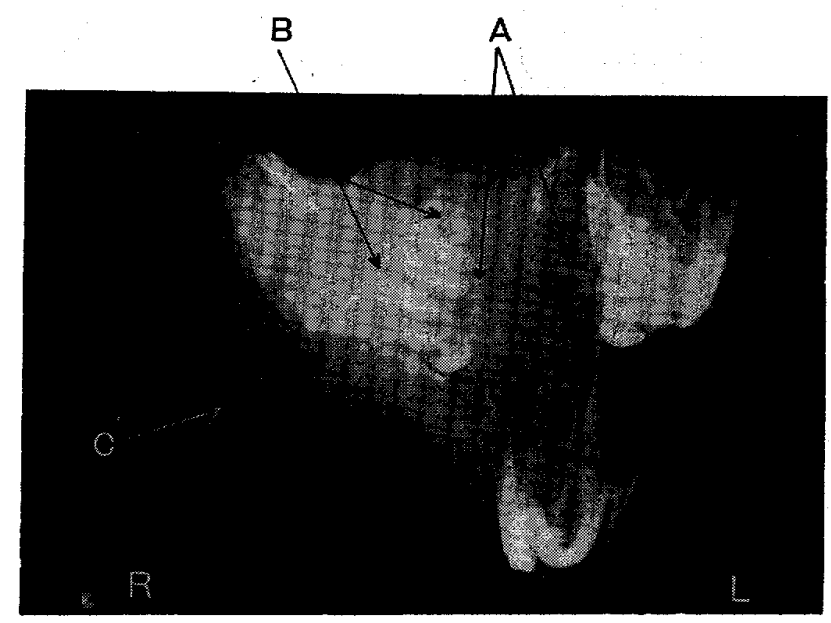

Fig.14 X-Ray photo on the twenty-eighth day (case No.45) A: clear bone absorption

B: teeth dislocated

C: clouded radioopaque areas, the size of a hen's egg, observed at the outer side of the maxillany sinus.

7 腫瘍割面の肉眼的観察; 上方は患側穊骨洞の一部 (No. 37, 40), 穊骨洞の全域 (No. 33, 34, 42, 43, 44）に達し，No. 42では，穊骨迷路より反対側の穊骨迷 路に達していた。また，鼻甲介を破壊，浸潤（No. 35， 36，38） し，前頭骨，前蝶形骨内（No. 45）へ達してい た。 下方は洞底の骨内 (No. 37，40)，上顎 歯槽突起の 田㐘根尖部 (No. $33,34,35,36,38,42,43,44$ ), あるいは口盖粘膜下 (No. 45) へ達するすのがみられ た. 前方は前鼻甲介の一部 (No. 37，40), 前 鼻甲介の 
中央 (No. 42，43，44）, あるいは前鼻甲介のほほ全域 （No. 33，34，35，36，38，45）を占拠していた. 後方 は上頢洞後壁内（No. 37，40)，涙骨の一部抒よび眼窝 前壁内に達し（No. 33，34，35，36，38，42，43，44, 45), 眼球を後方へ圧迫していた。乙の圧迫は，洞内の腫 瘍と頓部軟組織を占拠する腫瘍が接する煩骨眼窝突起部 および，眼曧の前壁において著明であった．内方は鼻側 壁骨内 (No. 37)，鼻腔の一部 (No. 33，40），あるいは 鼻腔の全域へ達し（No. 34，35，36，38，42，43，44， 45), No. 42では鼻中隔空より反対側の鼻 腔の一部へ腫 瘍がおよんでいた，後方は後鼻孔附近にまで浸潤（No 34，35，36，38，42，43，44，45）していた.また, 腫 瘍は鼻中隔に接し，乙れを左側へ彎曲させ（No. 35， 36，38，42，43，44，45), 鼻中隔空や穊骨 迷路附近汃 ら左側の鼻腔，笁骨部へ浸潤してゅくもの（No. 42，45 ）があった．外方は上䫇頝側骨壁内へ浸潤し，この部を 外方へ圧追する態度をしめすすの（No．40)，上顎洞 頓側骨壁を圧排破壊し，頓部 軟組 織へ浸潤し小指頭大 (No. 37)，小鵎卵大ないし 鵟卵大の 腫瘤を形成（No. 33，34，35，36，38，42，43，44，45）していた. 腫瘤 の中心部は同心円的な 壊死がみられ，3 例（No. 35， 38，45）に癌乳流出の所見が認められ，とくにNo. 45に は歯牙の転位が認められた。

これら腫瘤の基底部の骨，すなわち，上方は顎間骨前 頭枝，下方は上顎骨歯槽突起部の一部の骨は腫瘍で置換 され消失していた.

その他，No.39は洞内《腫瘍が限局しており，No.41 は，上顎洞底の前方部にチョコレート様あるいは血餅様 のものが観察された。

8 剖検所見; 12 例 (No. 33，34，35，36，37，38, 40，41，42，43，44，45）に変化加認められた. 右側顎 下リンパ節が】個（No.35，36，38，41，42，45）ない し2 個（No. 33，34，37，43，44）が大豆大に腫脤し， てのうち 5 例 (No. 33，35，38，42，45）では, 頸部リ ンパ節が工個，大豆大に腫脹していた。また，No.40で は，左側䫟下リンパ節のみ工個腫脹していた。

その他, 肺一 (+) (No. 37)，（H）（No. 42），（卅）

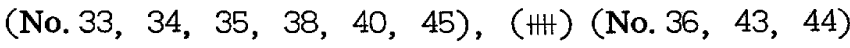
の転移所見があった．No.39は，転移と思われるような 所見は，見られなかった。

9 病理組織学的観察; 腫瘍の着床抢よび増殖を認め たものは, 13例（No.33〜45）中, 12例（No. 33, 34, 35, 36, 37, 38, 39, 40, 42, 43, 44, 45) で (Fig. 15），転移を認めたものは例（No. 33，34，35，36，
37, 38, 40,42, 43，44，45) であった. 従って, No. 39には転移を認めず，No.41には，腫演の転移はもちろ ん，着床さえ認めることはできなかった。

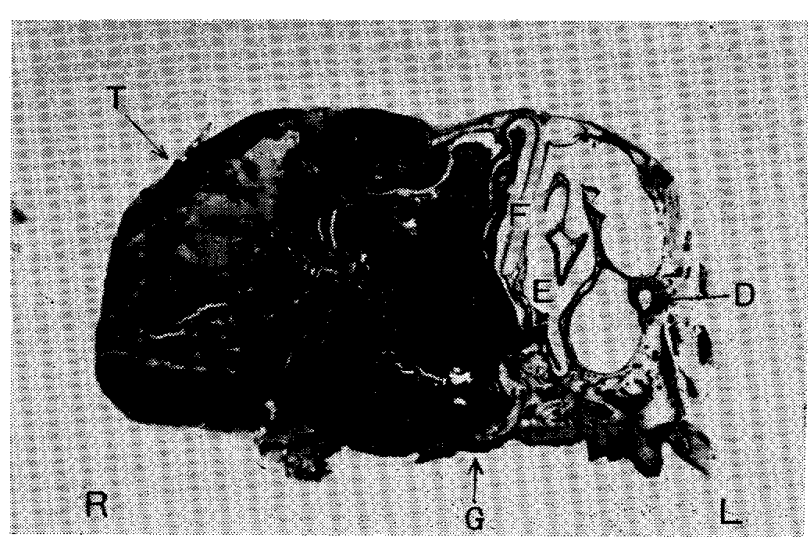

Fig.15 Histo-pathologic picture of the frontal sectional plane on the twenty-eighth day (case No. 44)

Deprivation of the proper maxillary sinus and cavum nasi due to the tumor growth

Shows the tumor, the size of a hen's egg.

$T$ : tumor: the tumor infiltrated and grew into the healthy cavum nasi.

$\mathrm{D}$ : canalis nasolacrimalis

E: cavum nasi

F: septum nasi: bent to healthy side.

G: palate: disfigured

10 TNM分類による観察； Stage I 亿該当するあのは なかった. Stage IIで $\mathrm{T}_{2} \mathrm{~N}_{0} \mathrm{M}_{0}$ のあの1例 (No. 39), Stage III $\mathrm{T}_{1} \mathrm{~N}_{1} \mathrm{aM}$ のあのI例 (No. 4I), Stage IVで $\mathrm{T}_{3} \mathrm{~N}_{2} \mathrm{bM}_{1}$ のむの1例 (No. 40)， $\mathrm{T}_{3} \mathrm{~N}_{3} \mathrm{bM}_{1}$ の あの 2 例 (No. 33, 37), $\mathrm{T}_{4} \mathrm{~N}_{3} \mathrm{bM} \mathrm{B}_{1}$ の の 8 例（No. 34, 35, 36, 38, 42, 43，44，45) が観察された.

\section{IV 粉括ならびに考按}

癌36)に対する基本的な治療姿勢は，免疫を含めて予防 の問題 $65,71,72)$ は別として，まず早期発見，早期治療であ り，てれらに関する多くの研究報告 $15,21,23,38,41,48)$ があ る。しかし，早期発見は，発現の部位，症状の展開など によっては，必ずしも容易でなく，とくに口埪領域にお いて上顎洞粘膜に原発すると考えられる上頢癌がその1 つにあげられる。

一方，乙のような䄆に対して，腫瘍の増殖態度 $24,25,42)$ とともに，乙れにとあなう全身的条件などの諸変化 5,9 , 20,66,74,78) および経過14)が， あらかじめ把握出来るなら ば, 早期発見が容易になり, 上り勃果的な治療を期待出 来るであろう．乙のために悪性腫煌に対する実験的研究 が続けられてきた。

悪性腫湢の增殖態度の実験的研究方法には，従来

I．動物の腫湯組織を，他の動物に移植し，その腫瘍 
の発育状態扔よび，その要約を研究する。

2. 健康組織に種々な刺激を加え腫瘍を発生させ，乙 れより腫湯発生の原因, 要約を研究する.

の2つが考えられている64).

Iの場合に扔ける癌研究に沶いては，1889年 Hanau13) が白ネズミに自然発生した扁平上皮癌を使用し, 動物に む可移植性の腫瘍があるという画期的な証明をとげて以 来, 腫場の同種移植成功例があいついで報告され，広く 各分野の研究に利用されてきた。

現在，日本で保存されている可移植性腫湢52,53,54)には

1 マウス

a 上皮性

39種類

b 非上皮性

17種類

c 白血球・リンパ腫・ウイルス腫痬・その他

64種類

2 ラット

a 上皮性

112種類

b 非上皮性

27 種類

c 白血球・リンパ腫・ウイルス腫瘍・その他

50 種類

3 ハムスター

10種類

4 ウサギ

5 ニワトリ

4 種類

6 イヌ

2 種類

0 種類

などがある。

私は，実験を行なうに先だち，乙れら三百数十種類の 腫湯のうち、すくなくとも

I．私の教室では，癌研究の一法として動注法による 癌の制圧を積極的に行なっている21). 従って, 動注法の 動物実験を行なうには，可移植性の固型腫瘍を持ち，し かあ出来るだけ人にちかい大きさの動物が望まれる.

2. 組織像が，人の顎口腔領域に圧倒的頻度で発生す る扁平上皮癌に近似するとと。などを満足する実験系を 選択する必要があると考えた。

したがって，動物としてはウサギ37,63)を選び，腫瘍と しては，4種類のうち Beryllium 骨肉腫は組織系が異 なるということ，Brown-Pearce Tumor は予備実験の 結果，移植陽性率が低かったとと7)，VX7 carcinoma は腫瘍の増殖経過が長く，観察に不便であるという理由 で除外し，組織系，可移植性，実験期間および観察に最 あ適当と考えられる，VX2 carcinoma を選んだ。

顎口腔領域における腫瘍 の移植 実験報告を渉編する 之, Table 2 の通りで, 内外ともにその数は少ない。な かでも，鬼を使用した実験は，顎口腔領域ばかりでな
く，他の領域でもマウス・ラットを用いた実験に比べれ ば，非常に少ない。

一方，鼻，副鼻腔内へ移植した実験は，Table 2 に示 すとおりで，兔を用いた実験報告は，芦原 3,4,67）（1928 年)，平野16）(1929年）のみである． 彼等は，加藤系家 兔肉腫を家兔の副鼻腔内一移植し，增殖に関する実験的 研究を報告しているが, 組織像が肉腫であり, 症例む少 ない.

諸家のVX2 carcinoma の腫瘍細胞浮游液調製法6,31， 34,40,44,61)は, Table 3 の通りで, 私の方法と稀釈液が異 なっている.

移植方法について，肉腫系であるが芦原）（1928年） は，針先が上顎洞鼻側壁に達した状態で注入，また平野 16）（1929年）は，同様な力法による壁内着床と，針先を 洞内に留めた状態で注入するる粘膜 上着床の両法によっ て，その增殖状態の違いを観察している.

私は，予備実験の結果，移植にあたり，刺入する針の 深さ，方向，注入速度によって腫痬堌殖態度が変化する ことを知った。そして，実験方法で記載したように極め て慎重に針を数mm進め，Fig. 2 亿示すように，針先が 洞腔内にとどまった状態とし，移植に際しては，上顎洞 粘膜表面に腫癔細胞が散乱するよう压力をかけて一気に 注入した。

芦原（1928年）ら4,16)の方法では，上類洞鼻側壁を越 えて鼻腔に達することああり，必ずしも一定の移植条件 が取られない難点があるのに対し，著者の方法では，ほ とんど同一の条件で洞粘膜上に打りる着床が得られる。

A 性別, 実験季節別, 移植時体重別, 移植時の家兔 の所見別に打ける移植成績

人の癌は, 性別, 年令により発現頻度が異なること2, 35,36,43,75)はすでに周知のとおりである.

そこで私は，乙の実験を通じて家鬼の性別，実験季節 別, 体重別に执いて移植成績に変化がみられるが゙うか 検索した。

まず，実験例を性別てついてみると，令は26例（No. $2,3,5,8,9,10,11,12,14,15,17,18$, $22,23,25,26,27,29,30,33,34,36,37,40$, 44，45）中，病理組織学的に VX2 carcinoma であるこ とが確認されたものは，移植７日目では 3 例（No. 3， 9，10）,14日目では 2 湖 (No.12，14）,21 日目以降任 全例 (No. 23, 25, 26, 27, 29, 30, 33, 34, 36, 37, 40,44,45)であった。ま地，古は19例（No. 1，4，6， $7,13,16,19,20,21,24,28,31,32,35,38$, 39，41，42，43）中，移植 7 日目では工例 (No. 4), 
Table 2 The table showing the reports of transplantation of experimental tumor on mandibulo-facial areas.

\begin{tabular}{|c|c|c|c|c|}
\hline year reported & reporter & $\begin{array}{l}\text { experimental } \\
\text { animals }\end{array}$ & kinds of tumor & region transplanted \\
\hline 1921 & TANAKA64) & rat & sarcoma & $\begin{array}{l}\text { intranasal cavity } \\
\text { intraparanasal sinuses }\end{array}$ \\
\hline 1921 & TANAKA ${ }^{64)}$ & mouse & carcinoma & $\begin{array}{l}\text { intranasal cavity } \\
\text { intraparanasal sinuses }\end{array}$ \\
\hline 1923 & $\begin{array}{l}\text { TOMITA66) } \\
\text { ASHIHARA66) }\end{array}$ & chick & sarcoma & $\begin{array}{l}\text { intrasubmucosa of } \\
\text { nasai cavity }\end{array}$ \\
\hline 1924 & HOSODA ${ }^{18)}$ & mouse & sarcoma & intrapar anasal sinuses \\
\hline 1924 & HOSODA ${ }^{18)}$ & mouse & carcinoma & intraparanasal sinuses \\
\hline 1927 & ASHIHARA 3 ) & mouse & carcinoma & intranasal cavity \\
\hline 1927 & ASHIHARA 3 ) & mouse & carcinoma & intranasal cavity \\
\hline 1928 & ASHIHARA4) & mouse & sar coma & intranasal cavity \\
\hline 1928 & ASHIHARA ${ }^{4)}$ & rabbit & sar coma & intranasal cavity \\
\hline 1929 & HIRANO ${ }^{16)}$ & rabbit & sar coma & intranasal cavity \\
\hline 1932 & YASUDA76.77) & rabbit & sar coma & intratonge \\
\hline 1951 & LUTZ ${ }^{39}$ & hamster & sar coma & \\
\hline 1952 & KAWAHARA27) & chick & sar coma & intramandibula \\
\hline 1952 & KAWAI 29) & rat & Wre sar coma & $\begin{array}{l}\text { hard tissues of } \\
\text { maxillary sinus }\end{array}$ \\
\hline 1952 & KAWAI 30) & chick & sar coma & bill of chicken \\
\hline 1953 & KAWAHARA28) & rat & sar coma & intra-upper and lower-jaw \\
\hline 1957 & $\begin{array}{l}\text { ICHIKAWA }{ }^{19)} \\
\text { ISOGAI 19) }\end{array}$ & rat & carcinoma & intramaxillary bone \\
\hline 1958 & TOMITA ${ }^{68,69)}$ & rabbit & $\begin{array}{c}\text { carcinoma } \\
\text { Brown-Pearce Tumor }\end{array}$ & intramandibula \\
\hline 1958 & TOMIT A 70$)$ & rat & sarcoma & $\begin{array}{l}\text { intramandibula } \\
\text { intrapulpa dentis }\end{array}$ \\
\hline 1960 & SHIMADA ${ }^{56)}$ & rat & sarcoma & Gl. submandibularis \\
\hline 1961 & INOUE 22) & rat & sarcoma & intramaxillary sinus \\
\hline 1965 & HOHKI ${ }^{17)}$ & rat & carcino-sarcoma & submandibular areas \\
\hline 1967 & ANDOH ${ }^{7}$ & rabbit & Brown-Pearce Tumor & intratongue \\
\hline 1968 & SAKAK। 50) & rat & sarcoma & intrapulpa dentis \\
\hline 1968 & $\left.A N D O H^{6}\right)$ & rabbit & $\checkmark \times 2$ carcinoma & intramaxillary sinus \\
\hline 1968 & KAWAKATSU31) & rabbit & $\vee \times 2$ carcinoma & Gl. submandibularis \\
\hline 1969 & MUSHIMOTO 45$)$ & rat & carcinoma & maxillary areas \\
\hline 1971 & ANDOH ${ }^{8)}$ & rabbit & $V \times 2$ carcinoma & intramandibula \\
\hline 1971 & KAWAKATSU ${ }^{32)}$ & rabbit & $v \times 2$ carcinoma & intramaxillary sinus \\
\hline
\end{tabular}


Table 3 The methods of transplantation in japan

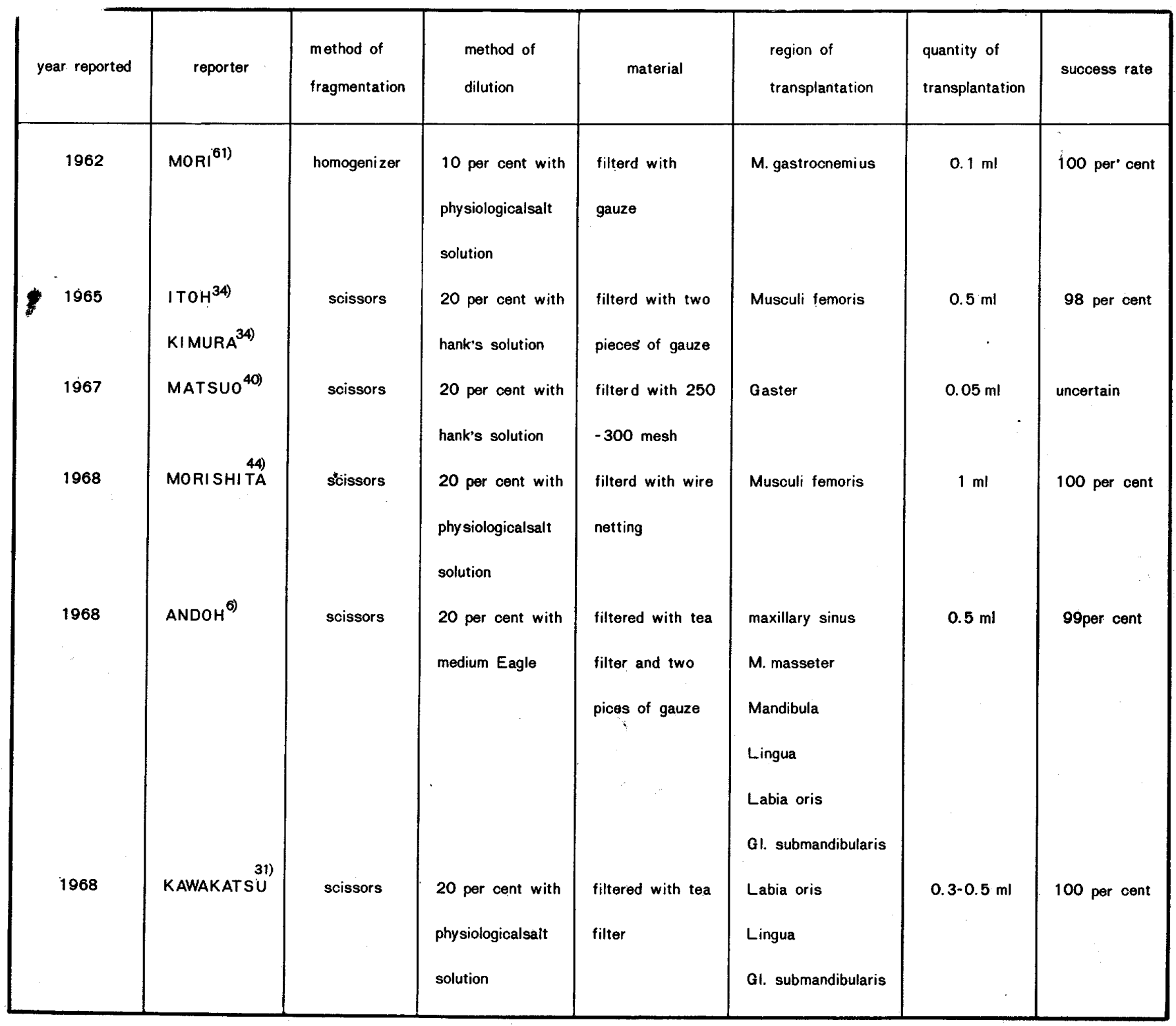


14日目では 4 例 (No. 13，16，20，21），21日目以降は No. 41 を除いて全例陽性で, 性別による差異は見出せな かった。

次に，事験季節別でみる亡，春は 12例 (No. 10, 11, $23,24,29,31,32,33,34,35,41,42)$ 中, 7 日目 のNo.10は陽性，No.11は陰性，21日目以降はNo.41を 除いて全例陽性であった。夏は12例（No. 1，12，13， $20,21,22,25,36,37,43,44,45)$ 中, 7 日目, 14 日目の1例（No. 1）を除いた 5 例（No. 12，13，20, $21 ， 22 ） ， 21$ 日目以降は全例陽性であった。秋は12例 (No. $2,3,4,5,6,14,15,16,26,27,28$, 38) 中，7日目，14日目の3 例 (No. 2，5，6）を除 いた 5 例（No. 3，4，14，15，16）および21日目以降 は全部陽性であった．また，冬は9例（No. 7，8， $9,17,18,19,30,39,40)$ のうち, 7 日目, 14日目 の 6 例中 3 例 (No. 9，17，18） および21日以降は全例 陽性で，実験季節別による差異はみられなかった。

次に，移植時体重別では， 1,550 2,000g のあの8 例 (No. 3, 12, 13, 17, 23, 24, 35, 38), 2,010 2,500gの6の33例 (No. 1, 2, 4, 5, 6, 7, 9, $10,11,14,15,16,19,20,22,25,26,27,28$, $29,30,31,32,33,34,36,37,39,40,41,42$, 43, 45), 2,510 3, 000gの屯の 4 例 (No. 8, 18, 21, 44) で, 移植後21日 以降も陰性であったものは，2,010 〜2,500gのうちに1例（No. 41）みられたにすぎず，移 植時体重別でも移植陽性率に差は認めなかった。

次に, 移植時家鬼の所見別による移植成績では, 移植 時鼻出血が10例 (No. $9,13,15,21,22,28,29$, 31，41，44）にみとめられたが，異常を認めないものと 移植成績に差はなかった。

以上のように，性別，体重別，実験季節別，および移 植時の鼻出血の有無などの条件の違いによって移植成績 に差がないととが確認された。

B V線学的観察と肉眼的観察との対比

後に記載している割面による観察と, ほぼ一致する所 見を得ているので簡単に述べる。

割面上で, 上萼洞内にチョコレート様あるいは血餅様 の附着物が認められた移植後 7 日群 (Fig. 5) は, レ線 学的に異常所見を認めることは出来なかった（No. I〜 11) (Fig. 4).

腫瘍が，上顎洞内にほぼ充満して認められた移植後14 日群 (Fig. 9，11) は, 上顎洞相当部に軽度の透過性减 少が観察され (No. 14, 21)，さらに上碩 洞外側部の骨 柱が一部消失した所見が認められた（No. 12，13）
(Fig. 10).

次に，周囲の組織内へ浸潤し，腫瘍が煩部軟組織に達 し，小指頭大から小鷄卵大の腫瘤形成が認められた移植 後21日群（Fig. 9，13）では，上顎洞および鼻腔に相当 する部が，一様に不透過像を呈し，この部の外方にあた る上顎頓側部の骨柱は乱机，骨皮質の断裂像もみられ た。また，上顎洞の煩部骨質外側には，骨皮質より小指 頭大の半球状，雲絮状の不透過像がみられた（No. 23〜 31) (Fig. 12).

次に，腫瘍がさらに増殖し，賽部軟組織に鵎卵大ない し鵟卵大の腫瘤が形成さ。れた移植後28日群（Fig. 14, 15）では，上顎洞部扣よび鼻腔は淡明な不透過像を呈 し，乙の外頰側部の骨柱，骨皮質は淡明となり，異常陰 影（No. 33，34，42，43，44)あるいは，また煩側骨壁の 消失がみられた（No. 35，38，45）。ささに，ての外頰 部には，山岳状に隆起した雲絮状のレ線陰影が観察され た. No. 45には，乙れらの所見の他に著明な骨吸収像, 㐘牙の転位像などが認められた（Fig. 14).

Table 2 に示すように, 顎口腔領域へ腫瘍を移植した 他の研究者では，いずれも病理組織学的検索が主体であ り、レ線学的観察を加えたものは，みあたらなかった。

\section{C 腫瘍の増殖態度}

私の実験では，割面上で，上顎洞内に全く変化が見ら れなかったむの8 例 (No. 1，2，5，6，7，8，

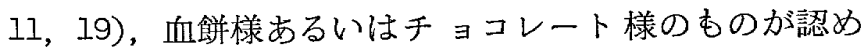
られたもの 9 例 (No. 3，4，9，10，15，17，18, $22 ４$ 1), 肉眼的にあきらかに腫瘍が確認出来たあの 28 例 (No. 12, 13, 14, 16, 20, 21, 23, 24, 25, 26, $27,28,29,30 ; 31,32,33,34,35,36,37,38$, $39,40,42,43,44,45)$ が観察されたが, これらの腫 瘍增殖態度について詳細にふれてみたい。

\section{1 腫瘍の着床について}

移植した腫瘍細胞浮游液が，どこに，どのような経過 をたどって着休するかについて，腫痬の増殖態度を知る 上で，特に興味が持たれる。

著者の実験で，この問題の対象になるのは，移植後7 日，14日群であるが，特に前記の血餅様あるいはチョコ レート様附着物が認められた 9 例 (No. 3，4，9， 10, 15, 17, 18, 22, 41) が検索の対象である.

著者は，Fig. 2 に示すように移植針が洞腔内に針先を とごめた状態で腫瘍細胞浮游液を注入した。 注入された 腫瘍細胞浮游液は洞壁をつたって流下し，上䕱洞の一番 底部あるいは陥凹部にあつまり，停滞したはずである。 したがって, 一定の時間, 一定の細胞数, 一定の培養液 
(Medium Eagle) が存在したと若えられる。乙の部分 が, 割面による腫瘍の肉眼的観察では, 洞 底 部 (No. $3 ， 4 ， 10,15,17,18,22,41)$ あるいは洞の側壁陥 回部（No. 9) にチョコレート様あるいは血餅 様のあの として観察され，腫瘍増殖の起点として確認されたわけ である：著者は，てのチョコレート様あるいは血餅様の あのと洞壁を含めた部分の病理組織標本を作製し，検索 した．チョコレート様あるいは血餅様の大部分は，壊死 組織様のものや炎症性細胞などからなり，新生血管, 腫 瘍細胞の増殖は認められなかった（Fig. 6). しかし， 洞粘膜に接する部分では活力のある腫瘍細胞が，炎症性 細胞に富んだ粘膜上皮下に洞粘膜上皮を排除または破壊 しながら，浸潤する像が認められた（Fig. 7，8）。 こ れらの工例（No. 3）において腫瘍細胞は，洞壁内軟組 織中に小胞巣を形成しながら，浸潤增殖していた。しか 屯この時期には，洞壁の骨組織に対する破壊は，全く認 ぬられず，軟組織のみに腫瘍細胞が浸潤していた。

一方，先人の報告を渉編すると， Table 2 のと抢りで あるが，マウス，ラットでは上顎洞周辺の解剖学的構造 が家鬼と異なる37,46)ので，乙の点で私の実験と共通点を むつ芦原4)(1928年)，平野16）(1929年）の家兔肉腫を 上顎洞内へ移植した報告は興味深い.

彼らは，加藤系肉腫を使った実験で健全な上䫟洞粘膜 外に移植した腫痬は，早晚，壊死におちいり，ここで発 育したり粘膜内へ侵入して増殖するととはなく，腫瘍の 着床はもっぱら粘膜損傷部に限っていたと記載し，その 理由として，I 腫痬細胞は栄養を摄取する途がない．

2 腫瑒細胞は空気に暴露されているため容易に壊死に おちいる。などをあげている。

私の実験結果之，芦原4（1928年)，平野16）(1929年） の記載では全く意見が異なっている，すなわち，私の実 験では，腫場の着床は健康な上顎洞粘膜上にみられたの にはんし，芦原4)，平野16）の実験では粘膜損傷部に限っ ていた。 その理由としては，移植に使用した腫瘍系の相 違，移植方法の相違，移植時の家兔の体位などが考えら れるが，その他の明確な根拠は明らか出来なかった。 しかし，乙れは極めて注目すべき所見亡考える。

2 腫瘍の増殖方向について

腫瘍着床の初期像である洞底部のチョコレート様ある いは血餅様の附着物（No. 3，4，9，10，15，17, 18，22，41）は，まず洞粘膜上皮下に浸潤（No. 21） し，洞内軟組織のみに次第に浸潤しながら，骨組織にそ って上顎洞内を充満（No. 14，39）した.

上頇洞内をほほ充満した次の時期では，周囲の鼻甲介
骨，鼻腔および節骨 洞の一部に 腫瘍が浸潤しはじめ( No. 12，13，）抢も亿洞之連絡をむつ粘膜下を浸潤しな がら隣接組織へおよんでいた。

次に，洞周囲の組織内への浸潤は，特に，上方は穊骨 洞から箱骨迷路をへて健側の穊骨迷路へ，内方は洞の内 侧壁加ら鼻㤎へ，さらに鼻中隔空を侵かし（No. 27,29， 42，45)，健側の鼻腔へ，また鼻腔や穊骨部 加ら後鼻孔 人 (No.34，35，36，38，42，43，44，45) 浸潤してい た. 外方は洞の外側壁を圧排する形態で浸潤し, 腫瑒が 頓部軟組織に達すると, 球状の腫瘤形成が認められた No. 23〜31，36，37，40). 乙れら一塊となった腫瘤中 心部は壊死飞打ちいり（No. $23 \sim 38 ， 40 ， 42 \sim 45$ ), 乙 れがさらに癌乳となって腫㽷外一流出するもの（No. 35 ，38，45）などが認められた。

また，腫演の増殖にとむなって歯牙の転位（No. 45）。 健側への鼻中隔彎曲 (No. 25，27，35，36，38，42, 43，44，45）などが認められた。

一方，注射針によって粘膜へ損傷を抢とした部分に腫 瘍が着床したものは，No. 16，20である。乙れらの着床 部は，注射針を刺入した上顎洞頓側骨壁部之考えられ， その増殖態度は, 煩部軟組織に半球状の腫痹形成が認め られるわりには，上顎洞内での腫瘍増殖が小さく，上顎 洞煩側骨壁部を中心とした部分に限局していて，上顎洞 底から原発し，洞内をほぼ充満して増殖したものと増殖 態度に明らかな相違が観察された。

しかし，乙の増殖形態がさらに進行し，移植後21日， 28日になるとほほとんど両者の区別はつかなかった．

以上のように，腫瘍は着 床後，上顎洞 粘膜下に浸潤 し，次第に洞内を充満した（Fig. 6，7，8）。すなわ ち, 腫瘍は骨組織汇沿って洞内軟組織へ浸潤した後, 洞 壁骨組織へ浸潤し，ついで破壊するというように，ま ず, 軟組織に浸潤し, 次に骨組織内一浸潤する態度が観 察された。 そして，煩骨眼窝突起部附近の腫瘍増殖は， 洞内軟組織内に增殖した腫痬之，骨組織内に浸潤した腫 疸が互に瘉合し，さらに腫瘤を拡大する増殖様式が認め られた (Fig. 13，15).

芦原4（1928年）は, 粘膜損傷部に初発した腫汮は，副 鼻腔内を大部分あるいは全く充満したあと，鼻甲介に沿 い固有鼻腔内に增殖し，鼻中隔を反対側に圧迫し，また は，中隔の腫瘍と鼻甲介の腫場と，相連続する場合むあ る、また一方，副鼻腔周囲の骨壁に沿い，乙れを破壤す ると同時に，鼻腔天蓋または鼻腔底部より鼻中隔に侵入 增殖し，その附着部を離断するのもある。このように進 んで反対側鼻腔に侵入増殖する．副 鼻腔 内を充した後 
に，皮下へ浸潤増殖するととが多く，回蓋へ達しとれを 破壊するのが最も避かった，と述べている。

平野16)（1929年）は，粘膜損傷部に初発した腫瘍は。 漸次増大し隣接器官である鼻腔諸器官, 鼻咽腔, 口盖, 嗅葉, 眼窩, 鼻涙管, 鼻背および反対側に侵入増殖して 一大腫瘍を形成し，被移植動物は，鼻腔狭窄のため呼吸 困難を扢とし死の転帰をとった，家兔肉腫は，主として 浸潤性の増殖を営み，血管リンパ管により転移性にも増 殖した。また，時には拡大性に增殖するあのああった。 と述べている。

芦原4）(1928年)，平野16）（1929年）の実験では，内 方つまり鼻中隔側への増殖方向が主体をなしているのに 比して，私の実験では，上顎洞粘膜と連絡が容易な力 向, すなわち, 上類洞頓側部, 篩骨迷路, 鼻中隔空, 後 鼻孔など骨が欠損している部分，換言すると抵抗の弱い 部分へ腫瘍の増殖方向が観察された．なかです，外方へ の増殖,つまり上顎洞煩部の海綿様骨部を浸潤破壊して 増殖するむのが圧倒的で 19例 (No. $23,24,25,26$, $27,28,29,30,31,33,34,35,36,37,38,42$, 43,44, 45) あった.

私の奏験結果と，芦原4（1928年)，平野16）(1929年） の報告では，全く䔬なる増殖方向を示している．乙の理 由としては, 実験に供した腫瘍系の相違, 移植方法の相 違, 実験数の相違などが考えられるが，これらについて は完全に明らかにすることは出来なかった。

\section{3 腫瘍の増殖速度について}

上顎洞内八移植した腫瘍が着床し，洞内をほぼ充満す るまで,溲殖は，一般に長い時間を要し，およそ18２0 日間であった。

イに，腫瘍は周囲の組織内一増殖するが，上顎洞外側 の菲薄な海綿様骨を浸潤破壇し, 煩部 軟組 織に達する を，腫瘍増殖速度は急速活発亡なった，すなわち，上顎 洞外側は菲薄な海綿様骨部からなっていて，小孔をもっ て上顎洞粘膜部之煩部軟組織とは交通がみられ，前方は 顎間骨，後方は上顎骨体，上方は顎間骨前頭枝，下方は 上㖽骨歯槽部にかとまれている。乙れら緻密な骨組織に 囲まれた菲薄な海綿様骨部が，腫瘍でまず侵され，次に 煩部軟組織内に達すると，急速な増殖態度を示し，突破 口となった海綿様骨部より，さらに大きな基底面をむつ 半球状の腫瘤形成が認められた. このととは煩側海綿様 骨部を破壊し，小指頭大の腫嵧を形成するのに約 3 週を 要したのに比して，その腫瘍が鴊卵大に達するのは，僅 かに工週間ほどであったことより明らかである。

したがって，軟組織での増殖は急速，活発であり，骨
組織での浸潤は抑制されるため, 上顎洞部分の腫瘍と頓 部軟組織の腫瘍との間に「頸」を持った増殖形式が観察 された。

芦原4（1928年），平野16）（1929年）の報告には乙 れら増殖速度についての記載はみられない。

著者の実験結果のように，腫瘍の増殖速度が浸潤部位 によって遅速があるとと, すなわち, 軟組織では急速, 活発に，骨組織では緩徐であったのは，怙そらく組織の 疎密から腫瘍の増殖に影響を与えたあのと思われ，以上 を模式図により示すと Fig. 16，17，180ようになる.

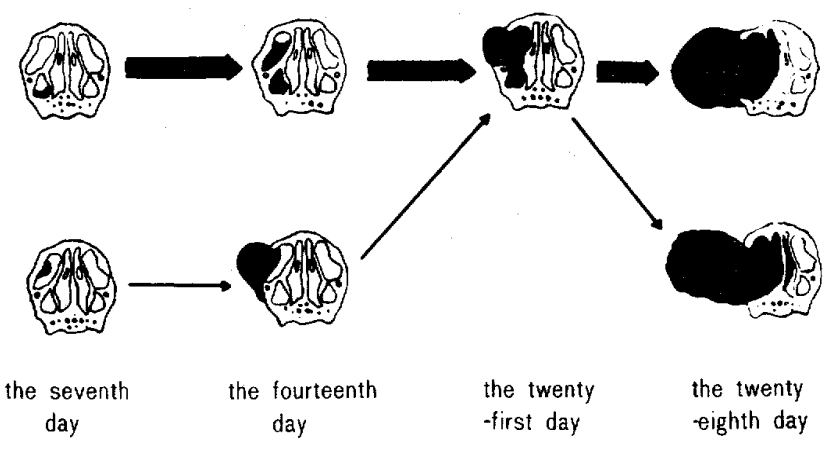

Fig.16 The mode of growth of VX2 carcinoma on the frontal sectional plane. The overwhelming growth shown by the arrow.

The blackened part of the picture shows the growth of the tumor.

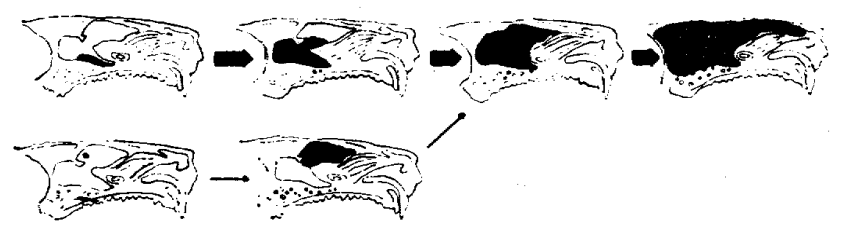

the seventh the fourteenth the twenty the twenty
day

Fig.17 The mode of growth of VX2 carcinoma on the sagittal sectional plane. The overwhelming growth shown by the arrow.

The blackened part of the picture shows the growth of the tumor.

D 人癌との対比について

人の上頟洞悪性腫瘍 $1,10,11,12,26,43,47,55)$ なかでも癌の発 育增殖態度については，とれを考察した報告は少なく， 本邦に执いては石倉24)(1943年), 三宅42（1960年）, 海江田 ${ }^{25)}$ (196I年) の少数例の報告がある.

これらによると, 原発性上顎癌の初期像は, 洞内腔に 向って乳嘴状に増殖し，洞粘膜上皮の傍側増殖像，円柱 上皮が扁平上皮に化生する像，あるいは上皮内癌の状態 などの所見が認められ, 上顎癌は多中心性に発生, 発育 する傾向が認められる。としている。そして，海江田 


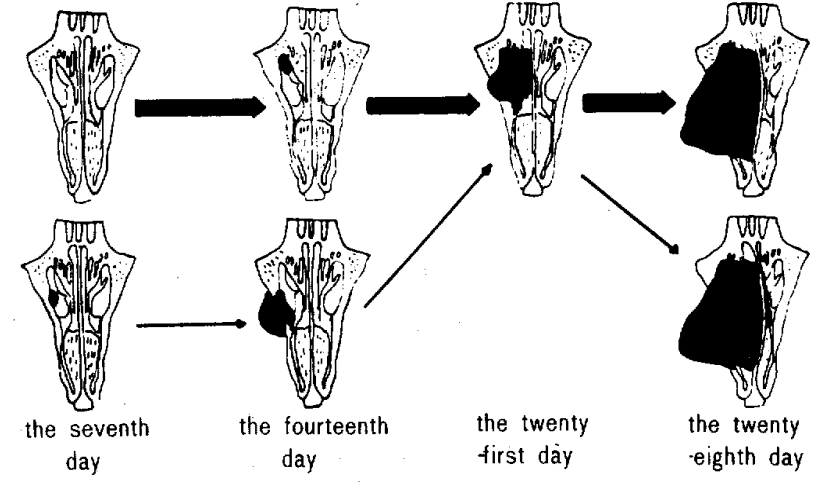

Fig.18 The mode of growth of the VX2 carcinoma on the horizontal sectional plane. The overwhelming growth shown by the arrow. The blackened part of the picture shows the growth of the turmor.

25）（1961年）は，上顮癌発生の初期は，ある点状物とし て存在するはずで, 洞内のどてかに好発部位というあの があるかも知れないと記載している。

腫瘍增殖過程について，山本73）(1949年）は，臨床的 所見之組織像加ら観察した結果, 上顎癌の原発推定部か ら、次のような発育方向をとる傾向がある．としてい る.

1 上顎洞内側壁に原発したと考えられたものは，第 エに中鼻道へ出て，それより鼻腔内を後鼻孔へ進む．第

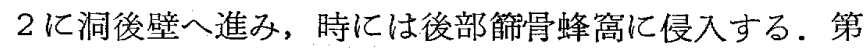
3に洞底抢よび後壁に進み，外壁に及ぶ．洞内に增殖す る場合は粘膜内を進むのであるが，その深層を通ること が最む多い。

2 上䔛洞後側壁に原発したと考えられた屯のは，第 Iに自然孔へ出て後鼻孔や後部節骨蜂窩に進む. 第 2 亿 眼窩底または前壁へ進む. 第 3 亿後側壁を破って翼状口 蓋窩の軟組織をおかす。

3 眼窩底に原発したと考えられたものは，第工に洞 粘膜の全層を通じ洞内に拡延する. 第 2 亿眼窩底の骨を 破壊して眼窩内に侵入する．第 3 に粘膜の上皮扔上び上 皮下層を通じて鼻腔に侵入し，一部は前部穊骨蜂窩に進 む.

4 洞底部に原発したと考えられたものは，多方面に 増殖する傾向がある，例えば，口蓋を破壊して菌肉や口 腔に出たり, 反対側の口蓋へ進む。顔面壁をおかし，こ れを融解する，鼻腔側壁に進み鼻孔に達する，と述べて いる.

以上の上うに，人癌の腫瘍増殖様式については検索例 が少く，推定の域をてえないのが現状である，乙のとと は止むを得ないことであろう。従って，実験による解明
が必要となってくる.

人癌との対比を考える場合に，まず問題となるのは細 胞の性質である．人癌は自然発生癌で体細胞からなり， VX2 carcinoma は移植癌で，移植する時点では他家細 胞22)である。しかしながら，本腫瘍がいったん着床し， 自律性増殖をはじめると，乙れはあはや人癌の場合と同 様の体細胞の癌であり，両者のあいだには本質的な相違 はないあの之考えられる。

次に問題之なるのは，人之家克の上䪽洞之その周囲の 解剖学的構築である。

人之家兔では，上顎洞の構成が異なっている．特に顔 面側は，人では維密な骨で構成されているのに対し，家 兔では菲薄な海綿様骨で構成されている。

また，人と家后では，鼻腔の構造が異なっている，人 の鼻腔は，鼻中隔が左右の鼻腔を完全にわけているのに 対し，家克の左右の鼻腔は，鼻中隔空で交通している。 このように人と家兔では, 解剖学的構築上の相違を考慮 にいれなければならない。

しかしながら，人と家鬼の腫瘍発育增殖様式を対比し てみると，著者の実験した家兔では，まず上澦洞粘膜を 腄煌組織内にとり入れ，破壊しながら洞内面骨壁に沿っ て増殖し(移植後7日目), ついにほほ上顎洞を充満す るに至った（移植後14日目）。ついで，扣もに洞と連絡 をむつ粘膜下を浸潤しながら管骨洞, 周团の骨内, 鼻腔 へ之増殖した。 そして，洞の外側壁の海綿様骨部を外方 一圧排する形態で浸潤し，煩部軟組織に達すると，球状 の腫瘤形成が認められた（移植後21日目）。次に，鼻腔 から鼻中隔空を侵して健側の鼻腔へ，あるいは穊骨迷路 の部分から健側の笁骨迷路へ，鼻腔や穊骨部加ら後鼻孔 一浸潤した。これら一塊となった腫瘍は，顔面側に巨大 な腫瘤を形成し, 癌乳流出, 眼裂閉鎖, 流涙, 鼻汁流 出, 呼吸困難, 䨑牙転位, などの所見を呈するに至った (移植後28日目).

一方, 人の腫演発育増殖様式は, 前に記載した海江田 25）（1961年）が述べているように，上顎洞粘膜が乳嘴状 に增殖し，洞内を充満する，次ぎに，腫湯の原発が，上 頷洞内側壁, 上顎洞後側壁, 眼窩底, あるいは洞底部で あって屯，粘膜下を浸潤しながら洞粘膜を腫場組織内に とり入れ，連絡をむつ粘膜下を浸潤しながら，周团の骨

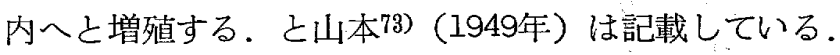

したがって，人と家鬼の腫痬発育増殖様式には，相共 通する経過をとることが考えられる。

これらの研究結果より，上顎癌の初期像は慢性上顎洞 炎にきわめて似ている49)といえ，そてで臨床上，両者の 
鑑別に一段と留意すべきであると，私の研究結果からも 云い得る。

\section{$\mathrm{V}$ 結 論}

著者は，上顎洞に原発する癌の増殖態度を解明する目 的で,VX2 carcinomaを家鬼上領洞内に移植した。移植 術式は, 従来から行なわれている細胞浮游液の組織内注 入法之異なり，上頼洞腔内に粘膜面を傷つけることな く, 粘膜面借散乱するような方法で移植し, 家兔の全身 ならびに局所の肉眼的, レ線学的, 腫瘍割面の肉眼的, 剖検, 病理組織学的㧍よび TNM 分類による観察を移植 後 7 日目 (11羽)，14日目 (I工羽)，21日目 (10羽)，28 日目 (13羽) に行ない, 次の結果を得た。

1 移植成績は, ほぼ100\%で, 家兔の性別, 移植時 体重別; 奏験季節別, 移植時の鼻出血の有無などの条件 の違いによって，移植成績に差を認めなかった．

2 移植した腫瘍細胞浮游 液は, 洞 壁をつたい流下 し，上顎洞の最底部あるいは陷凹部にあつまり，その健 康粘膜部分に着床した。

3 腫瘍は, 着床後, まず上顎洞粘膜下に浸潤したC 7 日目).つざに, 洞内粘膜执よび粘膜下組 織へ浸潤 し，次第に洞内を充満し (14日目)，ついに洞の外側壁 の海綿梯骨部を外方へ圧排する形態で浸潤し, 周囲骨組 織をあ浸潤破壞し（21日目），ついで，顔面煩側方向 に，特に急激に増殖発育した (28日目).

稿を終るにあたり，終始，御㥎篤なる御指導，御校閲 を賜った恩師池尻茂教授おおよび終始一貫した御助言を いただいた古本克磨助教授に深甚の謝意を表します。

また実験上, 種々の御協力をいただいた中島泰臣大学 院生, 中富俊介歯学士执よび第 2 口腔外科教室の諸兄に 厚く御礼を申し上げます。

\section{$\mathrm{VI}$ 参考文 献}

1. 浅并良三；上顎およびその附近の悪性 腫瘍：日耳 鼻, 61, 416, (1958).

2. 浅开良三; 上顎洞 : 日本癌治療学会雑誌, 5 (1), 173, (1970).

3. 声原. 勝; 可移植腫瘍ノ鼻腔内移植 (第 2 回報告), 甘日鼠癌腫並二白鼠癌腫 7 鼻腔内二移植セル実験成 績: 愛知医学雑誌, 34 (11), 85-115, (1927).

4. 芦原 勝; 可移植性腫瘍ノ鼻腔内移植 (第 3 回報告 ), 白鼠肉腫並二家兔肉腫 7 鼻腔内二移植セル実験 成績 : 愛知医学雑誌, 35 (5), 1-49, (1928)
5. 渥美剛重 ; 各種制癌剂動注時における口腔癌患者の 血清蛋白像ならびに血清鉄の変動に関する臨床的, 実験的研究 : 九州歯会誌, 22, 137-144, (1970).

6 . 安藤龍男; 家黾癌の移植実験 (第 2 報) VX2 carci noma について:九州歯会誌, 23 (2), 187, (1968).

7. 安藤龍男; 家鬼癌の移植実験. 1. Brown-Pearce Tumor の継代移植実験之家兔口腔領域の移植実験 について: 九州齒会誌, 23 (1), 86-95, (1968).

8. 安藤龍男, 池尻茂, 古本克磨; VX2 carcinoma $儿$ よる 反応性骨梁の 形成実験：日口 科誌，20（2）, 252, (1971).

9. 銅城将紘; 口腔癌患者における血清 LDH 活性值お よび血清LDH isozyme に関する臨床的，実験的研 究: 九州䨑会誌, 24 (6), 821-846, (1971).

10. 福田 敬; 上頢癌の病理組織学的研究, 特に腫瘍の 周囲軟部組織に及ぼす影響について：日本耳鼻咽喉 科学会々報， 64 (2)，319-332，(1961).

11. Geshickter, T ; Tumor of nasal and Paranasal cavities: Am. J. ca., 24, 637, (1935).

12. 後藤敏郎, 海江田紳, 藤本高明; 上顎癌に就て臨床 的㧍よび病理組織学的観察, 特にその増殖様式 ( 会)：日本癌学会22回総会記事, 293-294, (1964).

13. Hanau, A. ; Experimentelle Übertragung von Carcinom von Ratte auf Ratte : Langenbeck's Archiv., 39, 678, (1889).

14. 原 義雄, 川井和夫, 木村元, 藤宮松太郎, 藤崎 茂, 小越和栄; 癌患者の臨床経過と血清蛋白分割と 血清酵素活性：ガン新病誌，4，203-211，(1965).

15. 日戸修一; ガン化学療法の革命ーブレオマイシンを 追ってー，1-312，東京タイムス社 (東京)， (1970).

16. 平野 賛; 副鼻腔二於ケル腫瘍移植オコビ其増殖二 関スル実験的研究: 大日本耳鼻咽喉科会会報, 34 (12), 24-73, (1929).

17. 法貫 正; 移植腫瘍の転移に関する実験的研究.

1. 顎下部移植時の顎・頸部リンパ節への転移形成 について：歯科医学, 28 (6), 590-614, (1965).

18. 細田忠四郎; 副鼻腔二於ル悪性腫瘍ノ移植オョビ増 殖二関スル実験 : 日耳鼻，30 (4)，385-401， (1924).

19. 市川辰己, 磯貝豊; 可移植性マウス癌腫の顎部移植 成績 : 口外誌, 3 (3)，133-134，(1957).

20. 池尼 茂, 大曲靖夫; 口腔疾患の検查と診断：1- 
69, 医歯薬出版株式会社 (東京)，(1969）.

21. 池尻茂; 制癌剂による口腔癌の制圧一持続動脈内注 入法を中心として一：歯界展望，34 (1)， 1-4, (1969).

22. 井上隆之; 耳鼻咽喉領域への吉田肉腫移植の動物実 験ならびに腫瘍内血行系の考察：日耳鼻, 64 (3), 704-718, (1961).

23. 石川七郎; 癌の遠隔成績 : 日本癌治療学会誌, 5 (1), 117-201, (1970).

24. 石倉武雄; 上額癌腫に関する病理組織学的考察 : 日 耳鼻, 49 (11), 987, (1943).

25. 海江田紳；上顎洞悪性腫瘍の骨壁に対する侵襲につ いて：日耳鼻，64（9)，18-35，(1961)

26. 河辺義孝; 剖検診断に基いた上顎洞の転移について : 耳鼻咽喉，38 (8)，793-799，(1966).

27. Kawahara, M. ; On the transplantation of transplantable animal tumors into the hard tissues

(1) : Gann, 43, 292-294, (1952).

28. Kawahara, M. ; On the transplantation of transplantable animal tumors into the os tissues

: Gann, 44, 309-311, (1953).

29. 河合勇; 顎腫瘍の診断関する研究. 第工報吉田肉 腫の移植による実験的研究：日本外科学会雑誌，53 (9), 719, (1952).

30. 河合 勇; 顎腫瘍の揨断に関する研究. 第 2 報癌腫 におけるエナメル構造の電子顕微鏡像に対する臨床 的ならびに実験的観察 : 名古屋医学, 70 (2), 1541 -1556, (1955).

31. 川勝賢作, 森 昌彦, 杉村正仁, 松村智弘, 森下正 明, 河野孝行, 黒井満；VX2 carcinoma の口腔領 域に怙ける移植とその増殖態度について：第27回日 本癌学会総会, 181，(1968).

32. 川勝賢作，森 昌彦，杉村正仁，椿本雅有；vX2 carcinoma の上顎癌モデルについて：日ロ科誌, 20 (2), 252, (1971).

33. Kidd, J. G., and Rous, P. ; A transplantable rabbit carcinoma originating in a virus-induced papilloma and containing the virus in masked or altered form. : J. Expt1. Med., 71, 813-838, (1940).

34. 木村郁夫, 三宅恭司, 伊 藤洋平; 家 兔の可移植性 癌, VX2 およびVX7 の増殖態度について：第26回 日本癌学会総会, 272-273, (1967).

35, 北村武; 口咽喉癌 : 癌の臨床, 13 (5), 309-315,
(1967).

36. 厚生省編；厚生白書 : 23-29, (1968).

37. Krause, W. ; Die Anatomie des Kaninchens in topographischer und opertiver Rücksicht. : 2 Aufe., (1884).

38. 洼田博吉 ; シンポジウム I III ; 第 8 回日本癌治療 学会抄録集, 9-44, (1970).

39. Lutz, B. R., Fulton, G. P., Handler, A. H., ; The cheek pouch of the Hamster as a site for the transplantation of a Methylcholanthreneinduced Sarcoma : Cancer Research, II (I), 6466, (1951).

40. 松尾 裕, 関敦子, 服部理男, 北村達也, 牛尾杉 義，中尾喜久; VX2 癌による実験的胃癌に関する 研究（第 2 報）：第26回日本癌学会総会記事, 271 -272 , (1967).

41. 宮川 正, 柄川順；癌放射線治療の問題点：日本癌 治療学会誌, 5 (4)，409-414，(1970).

42. 三宅浩郷；大切片標本による上顎癌の病理組織学的 研究：日耳鼻. 63 (9)，57-92，(1960)。

43. 銊 哲也; 上顎癌の臨床的観察ならびに病理組織学 的研究：日耳鼻，63(3)，163-184，(1960)。

44. 森下正明; $\mathrm{X}$ 線照射の実験腫瘍におよぼす影響に関 する研究 : 大阪大学歯学雑誌, 13 (1), 139-145, (1968)

45. 虫本浩二; 腫瘍の転移に関する実験的研究，上顎部 移植時の顎・頸部 リンパ節への転移形成：歯科医 学, 32 (4), 487-507, (1969).

46. 長凧梧郎, 梅田干弘, 伏田宏, 宮下清; 各種動物 ( マウス・モルモット・家兔，犬）の鼻腔槛造ならび に嗅上皮の広がりについての比較考察：日耳鼻，64 (2), 126-127, (1961).

47. Öhngren, G. ; Malignant tumor of the maxilloethmoidal region: Acta Ctolaryng. Stookh. suppl., 19, 1-476, (1933).

48. 酒井俊一; 上顎癌の䛦断と進展度判定 : 耳鼻臨床, 62 (7), 809-817, (1969).

49. 酒井俊一, 藤崎茂已; 上靧癌と慢性副鼻腔炎々の相 関：耳鼻臨床，61，929-931，(1968）。

50. 栏 鉄也, 河畑邦夫; 多和肉腫のラット歯䯣内移植 そついて：第27回日本癌学会総会. (1968).

51. Stanfield ROGERS, M. D., John G. KiDD. M. D. and Peyton Rous, M. D. ; Relationships of the Shope papilloma virus to the cancers it de- 
termines in domestic rabbits : Acta Un, Int, Cancer, 16, 129-130. (1960).

52. 佐藤春郎, 佐藤 博, 井坂英彦, 吉田富三;日本で 維持されている可移植性腫瘍（1）：医学のあゆ み, 68 (10), 471-479, (1969).

53. 佐藤春郎, 佐藤 博, 井坂英彦, 吉田富三; 日本で 維持されている可移植性腫瘍 (2) : 医学のあゆみ, 68 (11), 521-530, (1969).

54. 佐藤春郎, 佐藤 博, 并坂英彦, 吉田富三 ; 日本で 維持されている可移植性腫瘍 (3) : 医学のあゆみ, 68 (12), 566-574, (1969).

55. 㤢藤彰吾; 上顎癌の病理組織学的研究（特に骨に対 する影響について）日本耳鼻咽喉科学会会報，64 (3), 719-734, (1961)

56. 島田牢四郎; 吉田肉腫を移植したラット顎下腺につ いて：荬科医学, 23 (5), 1503-1522, (1960).

57. Shope, R. E. ; A transmissible tumor-like condition in rabbits : J. Exptl. Med, 56, 793. (1932).

58. Shope, R. E. ; Infectious papillomatosis of rabbits with a note on the histopathology : J. Exp. Med. 58, 607-624, (1933).

59. Shope, R. E. ; Immunization of rabbits to infectious papillomatosis : J. Exptl. Med., 65, 219, (1937).

60. Shope, R. E. ; Are animal tumor viruses always virus-like? : J. Gen. phisiol., 45, 143, (1963).

61. Shyunichi MORI, M. D., Bayard CLARKSON, M. D., Elsie T. MASLE, R. N., and Walter LAWRENCE, Jr., M. D., ; An experimental perfusion system using the Rabbit VX2 carcinoma. I. Studies on the effect of drug perfusions and irradiation: JSR, 11 (4), 268-282, (1962).

62. Stone, R. S., Shope. R. E., \& Moore, D. H. ; Electron microscope study of the development of the papilloma Virus in the skin of the rabbit : J. Expt1. Med., 110, 543, (1959).

63. 高山昭三；ウサギの移植性腫瘍と原発癌：医学のあ ゆみ, 71 (5), 202-203, (1969).

64. 田中文男; 鼻及ビ副鼻腔二於ル悪性腫瘍ノ病理 : 大
日耳鼻, 25(3・4)，152-185，(1921)。

65. 田中富子； BCGと腫瘍細胞の direct contact による Immunotherapy：医学のあゆみ， 77 (11), 599604, (1970).

66. 玉利尚之; 諸種疾患患者の血漿中亜鉛扔よび銅量に 関する知見; ことに悪性腫煬について：九州蒾会 誌, 24 (5), 612-648, (1970).

67. 富田治郎, 芦原勝; 可移植性腫煌ノ鼻腔内移植 (第 1 回報告) 鶏肉腫 (大島系) 7 鶏鼻腔内二移植セル 実験成績 : 愛知医学雑誌, 30 (3), 433-439, (1923).

68. 冨田光男; Brown-Pearce家兔癌の同種動物顎内移 植実験（第 I 報）：名古屋医学, 75 (1), 1-8, (1958).

69. 冨田光男; Brown-Pearce 家鬼癌の同種動物顎内 移植実験（第 2 報）：名古屋医学，76(6)，11781181, (1958).

70. 冨田光男; 吉田肉腫の同種動物内移植実験; 名古屋 医学, 76 (8), 1511-1519, (1958)

71. 臼淵勇; 交叉兔疫によるハツカネズミで乳癌の自家 移植抑制：医学のあゆみ，61，692-696, (1967).

72. 臼淵勇; 癌化学療法における免疫の役割：日本癌治 療学会誌, 4, 70-74, (1968).

73. 山本宗路; 上顎癌の病理組織学的研究 : 耳鼻咽喉 科, 21 (5), 190-197, (1949).

74. 山村雄一, 螺良英郎, 青木隆一, 正木繁, 小倉剛 ; 肺癌の血清学的診断一特に酵素化学的ならびに免疫 化学的診断法について: 肺と心， 10，223-230, (1963).

75. 山下一郎; 口腔癌治療後の障害とその対策一口腔癌 治療体系に関する総合的研究一：日口外誌， 20 (2), 203-238, (1971).

76. 安田鉄次郎; 可移植性腫湯の舌内移植実験, (1) 可 移植性家兔肉腫の舌内移植 : 病理学紀要, 8 (3), 517-542, (1932).

77. 安田鉄次郎; 可移植性腫瘍の舌内移植実験. (2) 可 移植性家䳕肉腫の舌内移植: 病理学紀要, 8 (3), 543-568, (1932).

78. 吉田光孝, 吉場朗; LDHアイソザイムの臨休的心用 : 臨床病理, 17, 185-189, (1969). 